\title{
Thermodynamic Modelling of Dolomite Behavior in Aqueous Media
}

\author{
Tadeusz Michałowski ${ }^{1}$ and Agustin G. Asuero ${ }^{2}$ \\ ${ }^{1}$ Faculty of Engineering and Chemical Technology, Technical University of Cracow, 31-155 Kraków, Poland \\ ${ }^{2}$ Department of Analytical Chemistry, The University of Seville, 41012 Seville, Spain
}

Correspondence should be addressed to Tadeusz Michałowski, michalot@o2.pl

Received 20 August 2011; Revised 19 October 2011; Accepted 27 October 2011

Academic Editor: Jaime Wisniak

Copyright ( $(2012$ T. Michałowski and A. G. Asuero. This is an open access article distributed under the Creative Commons Attribution License, which permits unrestricted use, distribution, and reproduction in any medium, provided the original work is properly cited.

\begin{abstract}
The compact thermodynamic approach to the systems containing calcium, magnesium, and carbonate species is referred to dissolution of dolomite, as an example of nonequilibrium ternary salt when introduced into aqueous media. The study of dolomite is based on all attainable physicochemical knowledge, involved in expressions for equilibrium constants, where the species of the system are interrelated. The species are also involved in charge and concentration balances, considered as constraints put on a closed system, separated from the environment by diathermal walls. The inferences are gained from calculations performed with use of an iterative computer program. The simulated quasistatic processes occurred under isothermal conditions, started at a preassumed $\mathrm{pH}_{0}$ value of the solution where dolomite was introduced, and are usually involved with formation of other solid phases. None simplifying assumptions in the calculations were made.
\end{abstract}

\section{Introduction}

Dolomite $\left(\mathrm{CaMg}\left(\mathrm{CO}_{3}\right)_{2}\right.$, abbr. pr1) is perceived as an unusual, metastable mineral $[1,2]$, and its behavior is considered as one of the most exciting topics in geology [3]. Its chemical properties should be put in context with other, most important carbonate minerals: calcite $\left(\mathrm{CaCO}_{3}, \mathrm{pr} 2\right)$ and magnesite $\left(\mathrm{MgCO}_{3}, \mathrm{pr} 3\right)$ [4]. The trigonal structure of calcite is composed of alternate layers of calcium and carbonate ions. The crystal structure of magnesite is the same as one for calcite, and then magnesite properties are similar to those of calcite. However, a significant difference in Pauling's ionic radii: 99 pm (for $\mathrm{Ca}^{+2}$ ), 65 pm $\left(\right.$ for $\mathrm{Mg}^{+2}$ ), [5] causes an incompatibility of the cations in the same layer of dolomite structure. Crystal lattice of ideal dolomite $\left(M_{1}=\right.$ $\left.184.4 \mathrm{~g} / \mathrm{mol}, \rho_{1}=2.899 \mathrm{~g} / \mathrm{cm}^{3}\right)$ consists of alternating octahedral layers of $\mathrm{Ca}^{+2}$ and $\mathrm{Mg}^{+2}$ ions, separated by layers of $\mathrm{CO}_{3}{ }^{-2}$ ions [6]. Complete ordering is energetically favourable at lower temperatures. Presumably, it is the principal crystallographic constraint securing nearly ideal $(\mathrm{Ca}: \mathrm{Mg}=$ $1: 1)$ dolomite stoichiometry [6].

Ideal dolomite, $\mathrm{CaMg}\left(\mathrm{CO}_{3}\right)_{2}$, is a particular case $(x=$ 0 ) of the compound $\mathrm{Ca}_{1-x} \mathrm{Mg}_{1+x}\left(\mathrm{CO}_{3}\right)_{2}$ [7-10], considered as a result of partial disarrangement of $\mathrm{Ca}^{+2}$ and $\mathrm{Mg}^{+2}$ in structure of real dolomite. This disarrangement is evidenced by weak or diffuse spectral lines in the reflected X-ray diffraction patterns [11]. The composition of sedimentary dolomites is not exactly stoichiometric; it ranges from $\mathrm{Ca}_{1.16} \mathrm{Mg}_{0.84}\left(\mathrm{CO}_{3}\right)_{2}$ to $\mathrm{Ca}_{0.96} \mathrm{Mg}_{1.04}\left(\mathrm{CO}_{3}\right)_{2}$ (i.e., $-0.16<$ $x<0.04)$ [1]. The mineral $\mathrm{Ca}_{0.5} \mathrm{Mg}_{1.5}\left(\mathrm{CO}_{3}\right)_{2}(x=0.5)$ is named huntite. Sedimentary dolomites with $x>0$ are named calcium dolomites, and the ones with $x<0$ are named magnesian dolomites. The carbonate dominated by calcite $\left(\rho_{2}=2.71 \mathrm{~g} / \mathrm{cm}^{3}\right)$ is called limestone. Other carbonates: ankerite $\mathrm{Ca}(\mathrm{Fe}, \mathrm{Mg}, \mathrm{Mn})\left(\mathrm{CO}_{3}\right)_{2}$ and kutnohorite $\mathrm{Ca}(\mathrm{Mn}, \mathrm{Mg}, \mathrm{Fe})\left(\mathrm{CO}_{3}\right)_{2}$, with bivalent cations: $\mathrm{Fe}^{+2}$ and $\mathrm{Mn}^{+2}$, substituting a part of $\mathrm{Mg}^{+2}$ ions in the layered structure, enter also the dolomite group.

A rock formed by the replacement of dolomite with calcite [12]

$$
\mathrm{CaMg}\left(\mathrm{CO}_{3}\right)_{2}+\mathrm{Ca}^{+2}=2 \mathrm{CaCO}_{3}+\mathrm{Mg}^{+2}
$$

in dedolomitisation (calcitisation) process is named dedolomite [13]. Calcium ions in this process are provided, for example, by calcium-rich water, and magnesium ions 
are liberated. Molar volume of dolomite $(184.4 / 2.899=$ $63.608 \mathrm{~cm}^{3} / \mathrm{mol}$ ) is lower than two molar volumes of calcite $\left(2 \cdot 100.09 / 2.71=73.867 \mathrm{~cm}^{3} / \mathrm{mol}\right)$, and, therefore, reaction (1) causes an increase in the solid volume, equal (73.867 $63.608) / 63.608$, that is, ca. $16 \%$ [4].

Dedolomitisation is a particular case of a diagenesis [14], where an alteration of sediments into sedimentary rocks occurs. This process is accompanied by an increase in porosity, expressed by a percentage pore space. The pores form a void space or are filled with a fluid.

Dolomite is thermodynamically unstable, and dedolomitisation occurs under different conditions. The dedolomitisation in alkaline media is represented by reaction [15]

$$
\mathrm{CaMg}\left(\mathrm{CO}_{3}\right)_{2}+\mathrm{Ca}(\mathrm{OH})_{2}=2 \mathrm{CaCO}_{3}+\mathrm{Mg}(\mathrm{OH})_{2} .
$$

The reverse process (i.e., dolomitisation) occurs, for example, during evaporation of seawater. High temperatures enhance the dolomitisation process [16]. In dolomitisation, magnesium ions from seawater replace calcium ions in calcite, and dolomite is formed [17]. Dolomite growth is favoured by high $\mathrm{Mg} / \mathrm{Ca}$ ratios and high carbonate contents; this fact is predictable from Le Chatelier-Brown principle [18].

The main objective of this paper is to provide the way for better understanding the dolomite dissolution at different conditions [19] affected by $\mathrm{pH}$, initial concentration of dolomite $\left(C_{0}\right)$ in the system $\left([\mathrm{pr} 1]_{t=0}=C_{0}\right)$, and concentration of $\mathrm{CO}_{2}$. The knowledge of dissolution in acidic media is essential in aspect of improved recovery of oil and gas from sedimentary basins at low temperatures [20], whereas dedolomitisation in alkaline media plays a significant role in deteriorating the concrete structure $[15,21]$.

As will be stated in what follows, the solubility product value $\left(K_{\mathrm{spl}}\right)$ of dolomite is a critical factor in quantitative description of its behavior in the systems where dolomite is put in contact with aqueous solutions, containing dissolved $\mathrm{CO}_{2}$ and, moreover, a strong acid (e.g., $\mathrm{HCl}$ ) or a strong base (e.g., $\mathrm{KOH}$ ). This paper follows the one concerning struvite $[22,23]$, as another representative of a group of the nonequilibrium precipitates formed by ternary salts.

\section{Kinetics of Dolomite Dissolution and Stoichiometry}

In aqueous systems, ideal dolomite can be considered as an equimolar mixture of two carbonate components: calcite and magnesite, that is, pr1 $=$ pr2 + pr3. This simplifying assumption deserves some reservation, concerning relative rates of dissolution of the dolomite components; the literature provides ambiguous data in this respect, however. The results obtained according to AAS method by Lund et al. [24] exhibited stoichiometric dissolution of dolomite in relation to $\mathrm{Ca}$ and $\mathrm{Mg}$, whereas other experiments [25] showed that pure dolomite dissolves more slowly than pure calcite.

Dolomite exists in a variety of morphological forms [26]. Minerals with greater defect densities dissolve faster since their effective surface areas are greater than more perfect specimens of the same compound. The rate of surfacecontrolled dolomite dissolution is significantly less than one of calcite [27].

Dissolution rate increases with decreasing grain size [28]. The experiments done for kinetic purposes showed that the mass loss of single dolomite crystals [29] (in response to $\mathrm{pH}$ and $\mathrm{pC}_{\mathrm{CO}_{2}}$ ) or one for finely dispersed dolomite particles [27] (in response to $\mathrm{pH}$ ) was measured.

The dissolution of ionic crystals is a complex process, involving some surface and transportation phenomena. Ions are transferred from the surface of the solid material to an unsaturated solution [30]. The surface phenomena depend on the morphology (microstructure) of the crystals. The rate of any dissolution process is effected by surface and transport phenomena.

Kinetics of dolomite dissolution has been tested at different $\mathrm{pH}$ and temperatures [20]. According to a model by Busenberg and Plummer [29], the dissolution of dolomite is an effect of simultaneous action of $\mathrm{H}^{+}, \mathrm{H}_{2} \mathrm{CO}_{3}$, and $\mathrm{H}_{2} \mathrm{O}$.

The dissolution studies were usually carried out with suspensions or powdered materials employed, and the resulting concentration changes of $\mathrm{Ca}$ and $\mathrm{Mg}$ species in the bulk solution were measured [31]. For this purpose, in situ (e.g., conductometric, pH-metric, pH-static [32]) or ex situ (e.g., titrimetry, AAS [33]) methods of analysis were employed [30]. As an option, a rotating disc (RD) formed of dissolving dolomite attached at the end of rotating disc shaft was applied [34]. A loss in mass of the solid material was also measured [35].

It should be noted that repeated trials to precipitate ideal dolomite under laboratory conditions at room temperature were unsuccessful [36, 37]; dolomite was precipitated at elevated temperatures $\left(150-300^{\circ} \mathrm{C}\right)$ [38], for example, by heating calcite with $\mathrm{Mg}$ salt in aqueous media, at elevated $\mathrm{CO}_{2}$ pressures [39]. Dolomite is formed as a result of complex, not well-understood physicochemical phenomena $[40,41]$, because of the difficulties arising in preparation of stoichiometric dolomites [42]. These difficulties caused, among others, that the solubility product $\left(K_{\mathrm{spl}}\right)$ of dolomite in water

$$
K_{\mathrm{spl}}=\left[\mathrm{Ca}^{+2}\right]\left[\mathrm{Mg}^{+2}\right]\left[\mathrm{CO}_{3}^{-2}\right]^{2}
$$

measured according to different methods yielded inconsistent and unreliable results. The mechanism of dolomite formation in sedimentary environment (the so-named dolomite problem [43]) is not well understood, as hitherto [44].

\section{Principles of Simulation of Dolomite Dissolution}

3.1. General Remarks. Simulations are needed to check the models used. In modelling of chemical systems, different computer programs were developed. Among others, the Joint Expert Speciation System (JESS) computer program [45-48] is sometimes applied, for example, in [49]. A new approach, called Generalized Approach to Electrolytic Systems (GATES), was elaborated by Michałowski in 1992 and presented lately in some review papers [50-52] and in 


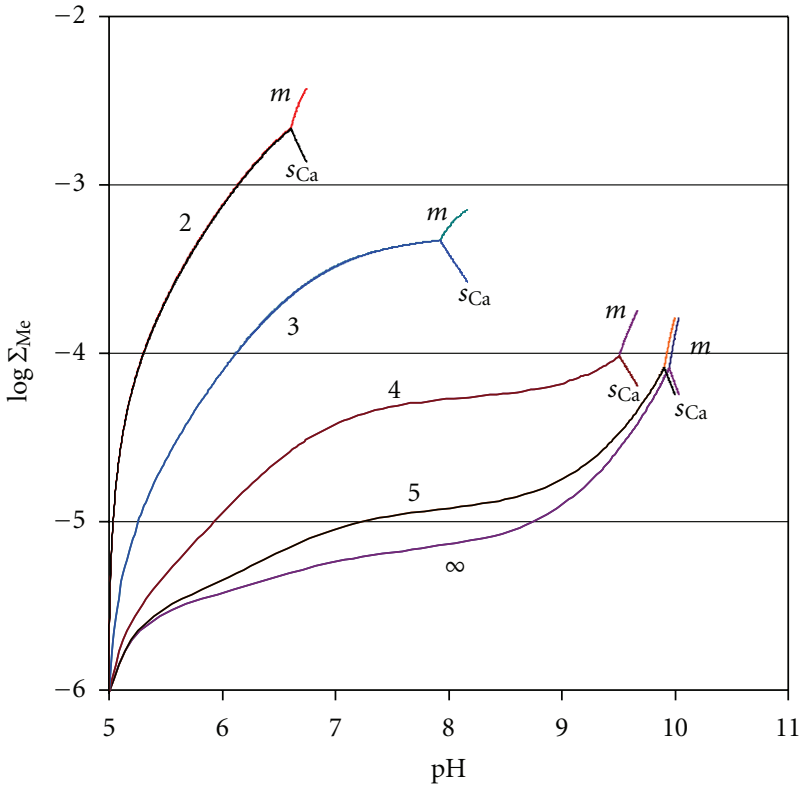

(a)

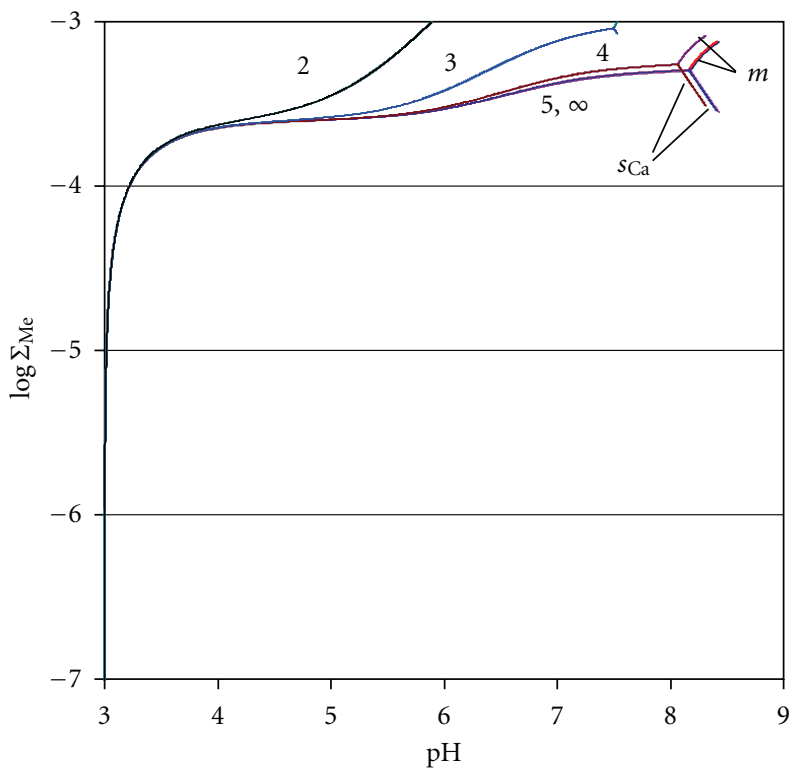

(c)

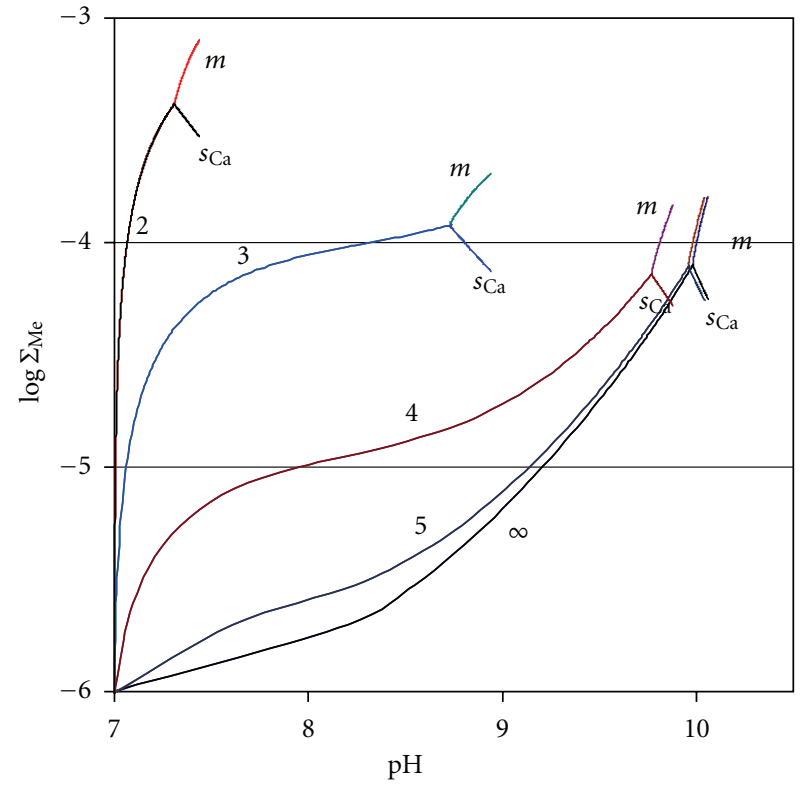

(b)

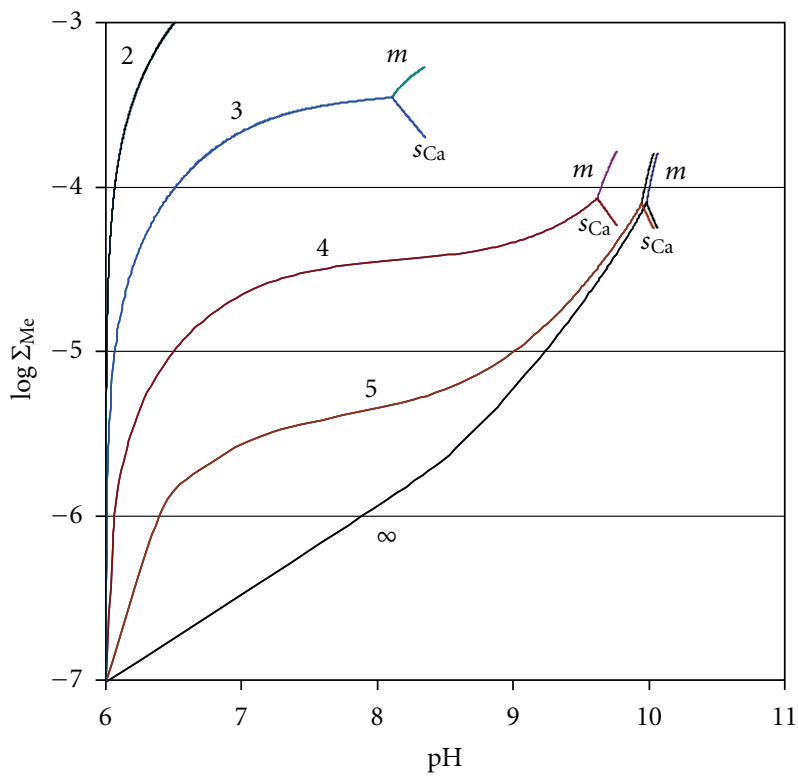

(d)

Figure 1: The $\log \sum$ Me versus $\mathrm{pH}$ relationships ((9), (10)) plotted for different sets of $\left(\mathrm{p} C_{0}, \mathrm{pC}_{\mathrm{CO}_{2}}, \mathrm{pH}_{0}\right)$ values: (a) (2, pC $\left.C_{\mathrm{CO}_{2}}, 5\right)$; (b) (2, $\left.\mathrm{p} C_{\mathrm{CO}_{2}}, 7\right)$; (c) $\left(3, \mathrm{p} C_{\mathrm{CO}_{2}}, 3\right)$; (d) $\left(3, \mathrm{p} C_{\mathrm{CO}_{2}}, 6\right)$. The $\mathrm{pC}_{\mathrm{CO}_{2}}$ values are indicated at the corresponding curves. For further details, see text.

textbooks $[53,54]$. For example, the systems with struvite $[22,23]$ were elaborated according to GATES.

The equilibria in the system with solid carbonates are affected by total concentration $\left(C_{\mathrm{CO}_{2}}\right)$ of carbonate species, introduced by $\mathrm{CO}_{2}$ dissolved in aqueous media, and by presence of $\mathrm{NaOH}\left(C_{b}\right)$ or $\mathrm{HCl}\left(C_{a}\right)$, used to moderate $\mathrm{pH}$ of the solution. At $C_{b}=C_{a}$, the effect is practically tantamount with absence of the related species in the solution, provided that $C_{a}$ and $C_{b}$ values are small; that is, the effect of ionic strength is negligible.
3.2. Equilibrium Constants. The set of equilibrium constants $[1,55-59]$ referred to the two-phase system in question is involved with solubility products $\left(K_{\mathrm{spi}}\right)$ of precipitates, (pri, $i=1, \ldots, 5$ ), expressed by ( 3 ) and

$$
\begin{aligned}
& {\left[\mathrm{Ca}^{+2}\right]\left[\mathrm{CO}_{3}^{-2}\right]=K_{\mathrm{sp} 2}\left(\mathrm{p} K_{\mathrm{sp} 2}=8.48\right),} \\
& {\left[\mathrm{Mg}^{+2}\right]\left[\mathrm{CO}_{3}^{-2}\right]=K_{\mathrm{sp} 3}\left(\mathrm{p} K_{\mathrm{sp} 3}=7.46\right),}
\end{aligned}
$$




$$
\begin{gathered}
{\left[\mathrm{Mg}^{+2}\right]\left[\mathrm{OH}^{-1}\right]^{2}=K_{\mathrm{sp} 4}\left(\mathrm{p} K_{\mathrm{sp} 4}=10.74\right)} \\
{\left[\mathrm{Ca}^{+2}\right]\left[\mathrm{OH}^{-1}\right]^{2}=K_{\mathrm{sp} 5}\left(\mathrm{p} K_{\mathrm{sp} 5}=5.03\right)}
\end{gathered}
$$

and soluble species (complexes, protonated forms):

$$
\begin{aligned}
{\left[\mathrm{MgHCO}_{3}^{+1}\right] } & =10^{1.16} \cdot\left[\mathrm{Mg}^{+2}\right]\left[\mathrm{HCO}_{3}^{-1}\right] \\
{\left[\mathrm{MgCO}_{3}\right] } & =10^{3.4} \cdot\left[\mathrm{Mg}^{+2}\right]\left[\mathrm{CO}_{3}^{-2}\right] \\
{\left[\mathrm{CaHCO}_{3}^{+1}\right] } & =10^{1.11} \cdot\left[\mathrm{Ca}^{+2}\right]\left[\mathrm{HCO}_{3}^{-1}\right] \\
{\left[\mathrm{CaCO}_{3}\right] } & =10^{3.22} \cdot\left[\mathrm{Ca}^{+2}\right]\left[\mathrm{CO}_{3}^{-2}\right] \\
{\left[\mathrm{HCO}_{3}^{-1}\right] } & =10^{10.33-\mathrm{pH}} \cdot\left[\mathrm{CO}_{3}^{-2}\right] \\
{\left[\mathrm{H}_{2} \mathrm{CO}_{3}\right] } & =10^{6.38-\mathrm{pH}} \cdot\left[\mathrm{HCO}_{3}^{-1}\right] \\
{\left[\mathrm{MgOH}^{+1}\right] } & =10^{2.57} \cdot\left[\mathrm{Mg}^{+2}\right]\left[\mathrm{OH}^{-1}\right] \\
{\left[\mathrm{CaOH}^{+1}\right] } & =10^{1.3} \cdot\left[\mathrm{Ca}^{+2}\right]\left[\mathrm{OH}^{-1}\right] \\
{\left[\mathrm{H}^{+1}\right]\left[\mathrm{OH}^{-1}\right] } & =K_{\mathrm{w}}(\mathrm{pK} \mathrm{w}=14.0)
\end{aligned}
$$

One should be noted that soluble complex species: $\mathrm{MgCO}_{3}$ and $\mathrm{CaCO}_{3}$, characterized by stability constants, are different from the precipitates: pr2 $=\mathrm{CaCO}_{3}$ and pr3 $=$ $\mathrm{MgCO}_{3}$, characterized by the solubility products $\left(K_{\text {spi }}, i=\right.$ 2, 3) values.

The $\mathrm{p} K_{\mathrm{sp} 1}$ values for dolomite reported in the literature range from ca. 16.5 to $19.35[37,55,56,60,61]$, that is, within ca. 3 units. Some inferences [37] lead to the conclusion that the most probable $\mathrm{p} K_{\mathrm{sp} 1}$ value is $17.2 \pm 0.2$. In this context, the value 19.35 taken in [55] seems to be excessively high. Such diversity in $\mathrm{p} K_{\mathrm{sp} 1}$ value may reflect the difficulties involved with obtaining stoichiometric dolomite.

The inequality $K_{\mathrm{sp} 1}<K_{\mathrm{sp} 2} \cdot K_{\mathrm{sp} 3}$, that is, $\mathrm{p} K_{\mathrm{sp} 1}>$ $\mathrm{p} K_{\mathrm{sp} 2}+\mathrm{p} K_{\mathrm{sp} 3}$, valid for all $K_{\mathrm{sp} 1}$ values quoted above, expresses a kind of synergistic effect securing almost perfect arrangement of $\mathrm{Mg}^{+2}$ and $\mathrm{Ca}^{+2}$ ions in area of the corresponding planes of dolomite crystallographic structure.

The values for stability constants of soluble complexes: $\mathrm{Mg}(\mathrm{OH})_{2}$ and $\mathrm{Ca}(\mathrm{OH})_{2}$, introduced for calculations in [55], are highly controversial and then were omitted in the related balances formulated below. In this context, the complexes $\mathrm{MgOH}^{+1}$ and $\mathrm{CaOH}^{+1}$ and their stability constants are well established.

The dissolution of dolomite ( $p r 1)$ proceeds up to the saturation of the solution against the corresponding precipitate. Provided that the solution is unsaturated against the corresponding solid phase (pri), the expression for the related solubility product $\left(K_{\text {spi }}\right)$ is not valid, under such conditions. For this purpose, the expressions

$$
\begin{aligned}
& q_{1}=\frac{\left[\mathrm{Ca}^{+2}\right]\left[\mathrm{Mg}^{+2}\right]\left[\mathrm{CO}_{3}{ }^{-2}\right]^{2}}{K_{\mathrm{sp} 1}}, \\
& q_{2}=\frac{\left[\mathrm{Ca}^{+2}\right]\left[\mathrm{CO}_{3}^{-2}\right]}{K_{\mathrm{sp} 2}}, \\
& q_{3}=\frac{\left[\mathrm{Mg}^{+2}\right]\left[\mathrm{CO}_{3}^{-2}\right]}{K_{\mathrm{sp} 3}}, \\
& q_{4}=\frac{\left[\mathrm{Mg}^{+2}\right]\left[\mathrm{OH}^{-1}\right]^{2}}{K_{\mathrm{sp} 4}}, \\
& q_{5}=\frac{\left[\mathrm{Ca}^{+2}\right]\left[\mathrm{OH}^{-1}\right]^{2}}{K_{\mathrm{sp} 5}}
\end{aligned}
$$

related to all possible precipitates (pri, $i=1, \ldots, 5)$ were considered.

3.3. Formulation of the Dolomite Dissolution Model. We refer to the system obtained after introducing $m_{1} \mathrm{~g}$ of dolomite into $V \mathrm{~mL}$ of aqueous solution with dissolved $\mathrm{CO}_{2}\left(C_{\mathrm{CO}_{2}}\right)$, $\mathrm{NaOH}\left(C_{b}\right)$, and/or $\mathrm{HCl}\left(C_{a}\right) ; \mathrm{NaOH}$ and/or $\mathrm{HCl}$ are used to moderate $\mathrm{pH}$ value of the solution. Assuming that the volume change resulting from addition of pr1 is negligible, and denoting current $(t \geq 0)$ concentration of pr1 by [pr1], $[\operatorname{pr} 1]_{t=0}=C_{0}=\left(10^{3} \cdot m_{1} / M_{1}\right) / V$, we get the concentration and charge balances

$$
\begin{aligned}
F_{1}(\mathbf{x})= & {[\mathrm{pr} 1]+\sum \mathrm{Mg}-\mathrm{C}_{0}=0 } \\
F_{2}(\mathbf{x})= & {[\mathrm{pr} 1]+\sum \mathrm{Ca}-\mathrm{C}_{0}=0 } \\
F_{3}(\mathbf{x})= & 2[\mathrm{pr} 1]+\left[\mathrm{MgHCO}_{3}^{+1}\right]+\left[\mathrm{MgCO}_{3}\right] \\
& +\left[\mathrm{CaHCO}_{3}^{+1}\right]+\left[\mathrm{CaCO}_{3}\right]+\left[\mathrm{H}_{2} \mathrm{CO}_{3}\right] \\
& +\left[\mathrm{HCO}_{3}{ }^{-1}\right]+\left[\mathrm{CO}_{3}^{-2}\right]-\left(2 \mathrm{C}_{0}+\mathrm{C}_{\mathrm{CO}_{2}}\right)=0 \\
F_{4}(\mathbf{x})= & {\left[\mathrm{H}^{+1}\right]-\left[\mathrm{OH}^{-1}\right]+\Delta+2\left[\mathrm{Mg}^{+2}\right]+\left[\mathrm{MgOH}^{+1}\right] } \\
& +2\left[\mathrm{Ca}^{+2}\right]+\left[\mathrm{CaOH}^{+1}\right]+\left[\mathrm{MgHCO}_{3}^{+1}\right] \\
& +\left[\mathrm{CaHCO}_{3}^{+1}\right]-\left[\mathrm{HCO}_{3}^{-1}\right]-2\left[\mathrm{CO}_{3}^{-2}\right]=0,
\end{aligned}
$$

where

$$
\Delta=C_{b}-C_{a}
$$

the expressions:

$$
\begin{gathered}
\sum \mathrm{Mg}=\left[\mathrm{Mg}^{+2}\right]+\left[\mathrm{MgOH}^{+1}\right]+\left[\mathrm{MgHCO}_{3}^{+1}\right]+\left[\mathrm{MgCO}_{3}\right] \\
\sum \mathrm{Ca}=\left[\mathrm{Ca}^{+2}\right]+\left[\mathrm{CaOH}^{+1}\right]+\left[\mathrm{CaHCO}_{3}^{+1}\right]+\left[\mathrm{CaCO}_{3}\right]
\end{gathered}
$$




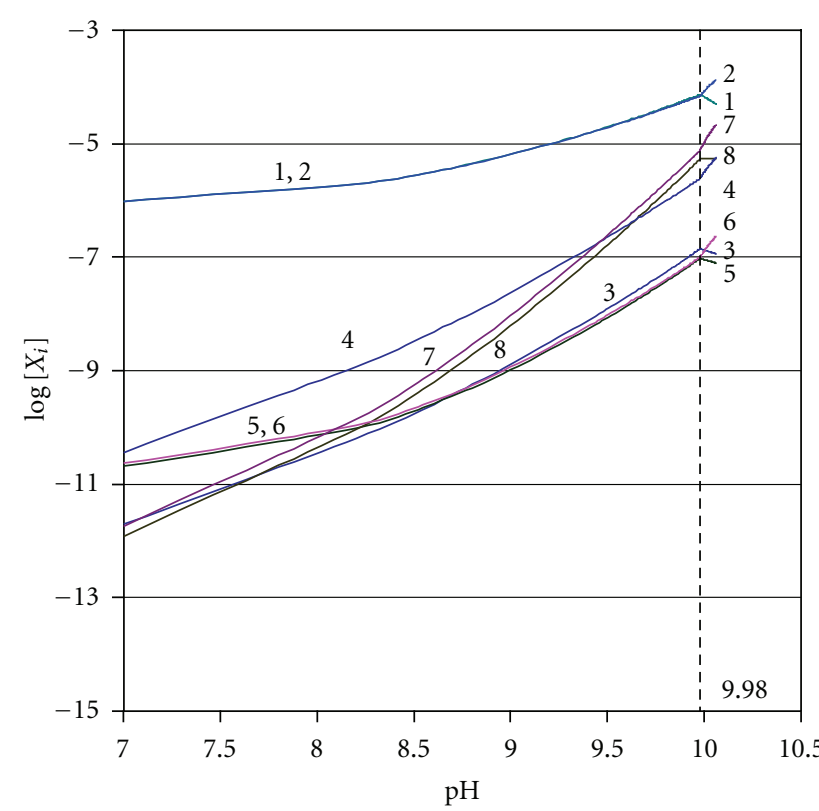

(a)

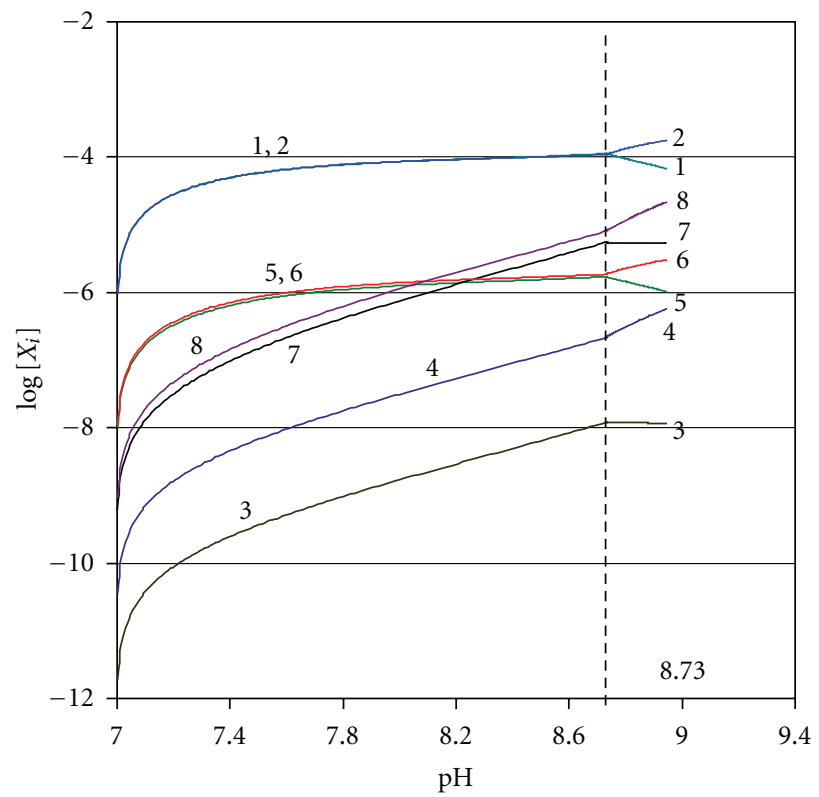

(c)

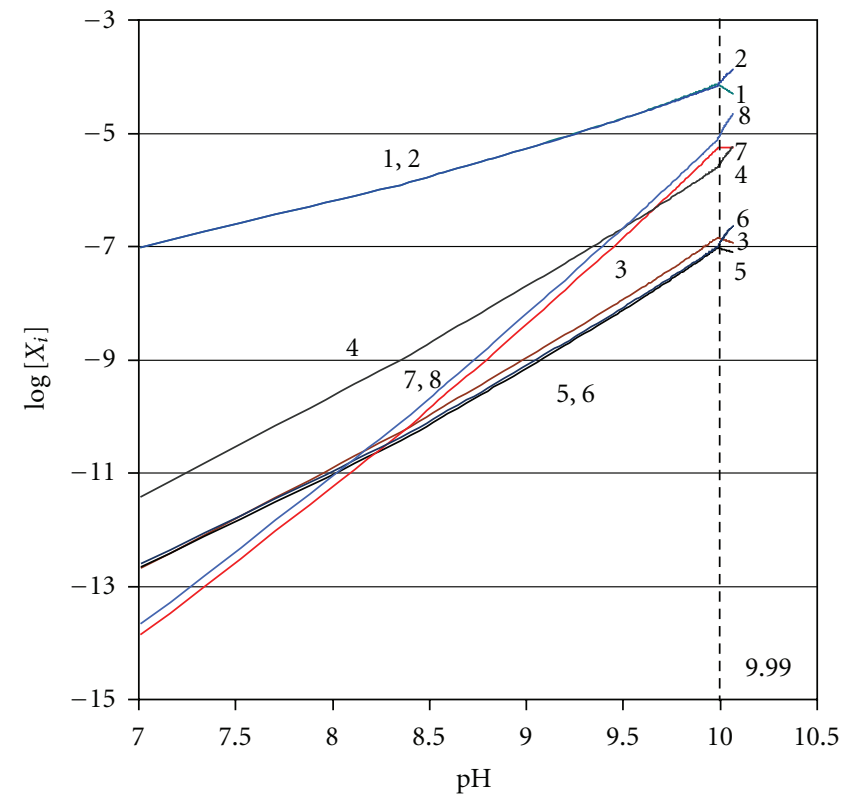

(b)

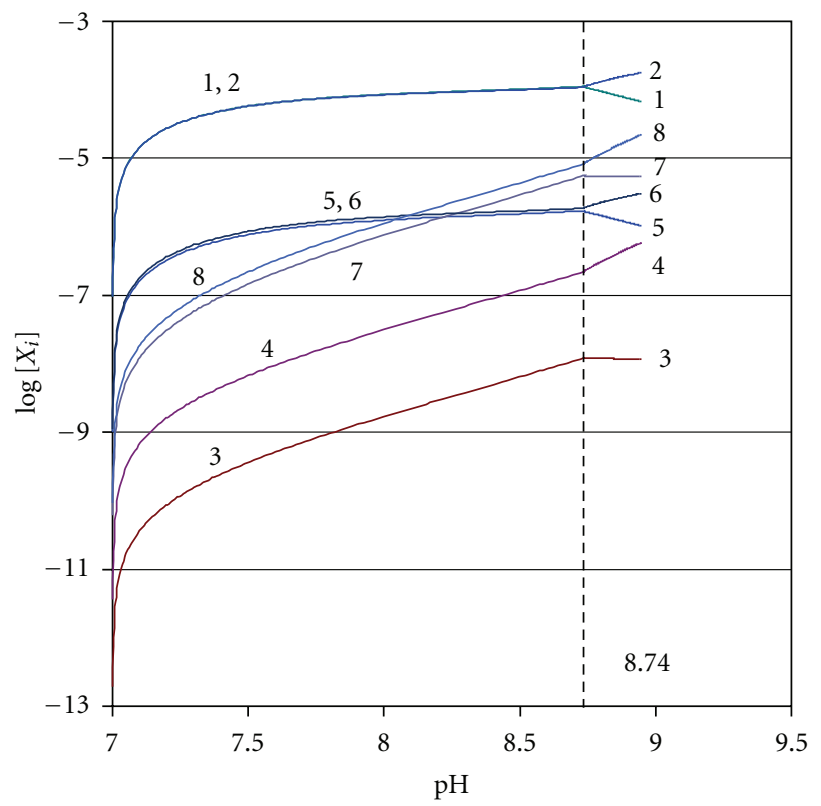

(d)

Figure 2: The $\log \left[X_{i}\right]$ versus $\mathrm{pH}$ relationships plotted for different sets of $\left(\mathrm{p} C_{0}, \mathrm{pC}_{\mathrm{CO}_{2}}, \mathrm{pH}_{0}\right)$ values: (a) $(2, \infty, 7)$; (b) (2, 3, 7); (c) (3, $\infty, 7)$; (d) $(3,3,7)$ for different soluble species $X_{i}$ indicated at the corresponding curves: $1-\mathrm{Ca}^{+2}, 2-\mathrm{Mg}^{+2}, 3-\mathrm{CaOH}^{+1}, 4-\mathrm{MgOH}^{+1}$, $5-\mathrm{CaHCO}_{3}{ }^{+1}, 6-\mathrm{MgHCO}_{3}{ }^{+1}, 7-\mathrm{CaCO}_{3}, 8-\mathrm{MgCO}_{3}$.

involve all soluble magnesium and calcium species; $\mathbf{x}=$ $\left[x_{1}, x_{2}, x_{3}, x_{4}\right]^{\top}$ is the vector of independent variables specified below. The number of variables forming the vector $\mathbf{x}$ is equal to the number of equations

$$
F_{i}(\mathbf{x})=0 \quad(i=1, \ldots, 4)
$$

specified above.
3.4. Calculation Procedure. The relations (11) are valid, if $\mathbf{x}$ is chosen properly. For any other vector $\mathbf{x}^{\prime}, \mathbf{x}^{\prime} \neq \mathbf{x}$, at least one of the functions (11) differs from zero, and then

$$
F\left(\mathbf{x}^{\prime}\right)=\sum_{i=1}^{4}\left[F_{i}\left(\mathbf{x}^{\prime}\right)\right]^{2}>0
$$

The calculation procedure is based on minimizing principle, quite analogous to one presented in $[22,23]$. According to 
this approach, the sum of squares (12) is taken as the minimized function.

In a dynamic process, as the dissolution of pr1 is, a choice of $\operatorname{ppr} 1=-\log [\operatorname{pr} 1]$ as the steering variable is advised; the value of [pr1] changes during the pr1 dissolution. The next step is the choice of independent variables, $x_{i}=x_{i}(\operatorname{ppr} 1)$, $i=1, \ldots, 4$. The $x_{i}$ values are involved with concentrations of some independent species. In our case, the best choice is $\mathbf{x}=\left[x_{1}, x_{2}, x_{3}, x_{4}\right]^{\top}=\left[\mathrm{pH}, \mathrm{pHCO}_{3}, \mathrm{pMg}, \mathrm{pCa}\right]^{\top}$, where $\mathrm{pH}=-\log \left[\mathrm{H}^{+1}\right], \mathrm{pHCO}_{3}=-\log \left[\mathrm{HCO}_{3}{ }^{-1}\right]$, $\mathrm{pMg}=$ $-\log \left[\mathrm{Mg}^{+2}\right], \mathrm{pCa}=-\log \left[\mathrm{Ca}^{+2}\right]$ were considered as independent variables. A choice of $\mathrm{p} X$ indices, not concentrations $[X]$, resulted from the fact that $10^{-\mathrm{p} X_{i}}>0$ for any real $\mathrm{p} X_{i}=-\log \left[X_{i}\right]$ value, $\mathrm{p} X_{i} \in \mathfrak{R}$. The third step is the choice of numerical values for components of the starting vector $\mathbf{x}^{\prime}=\mathbf{x}^{*}$; if $\mathbf{x}^{*} \neq \mathbf{x}$, one can expect that $F\left(\mathbf{x}^{*}\right)>0$ (12). The $x^{*}$ value is referred to particular value of the steering variable, $x^{*}=\mathbf{x}^{*}(\operatorname{ppr} 1)$, for example, to ppr1 $=-\log C_{0}$. The step $\Delta \mathrm{ppr} 1$ is needed, and initial steps $\Delta \mathrm{p} X_{i}$ for $\mathrm{p} X_{i}$ and lower $\left(\mathrm{p} X_{i, \text { inf }}\right)$ and upper $\left(\mathrm{p} X_{i, \text { sup }}\right)$ limits for expected $\mathrm{p} X_{i}$ values are also required by the iterative computer programs applied in the minimization procedure.

The searching of $\mathbf{x}(\operatorname{ppr} 1)$ vectors, where $F(\mathbf{x}(\operatorname{ppr} 1))$ is close to zero for different ppr 1 values, can be made according to MATLAB iterative computer program. The searching procedure satisfies the requirements put on optimal $\mathbf{x}(\operatorname{ppr} 1)$ values - provided that the $F\left(\mathbf{x}^{\prime}\right.$ (ppr1)) value (12), considered as optimal one, is lower than a preassumed, sufficiently small $\delta$-value

$$
F\left(\mathbf{x}^{\prime}(\operatorname{ppr} 1)\right)<\delta .
$$

Then we consider that the equality $\mathbf{x}^{\prime}(\operatorname{ppr} 1)=\mathbf{x}(\operatorname{ppr} 1)$ is fulfilled. It means that $F_{i}(\mathbf{x}(\operatorname{ppr} 1)) \cong 0$ for all $i=1, \ldots, 4$, that is, (7) are fulfilled simultaneously, within tolerable degree of proximity assumed for all ppr1 values taken from defined ppr1 interval. If pr 1 dissolves wholly, the ppr 1 covers the interval from $\mathrm{p} C_{0}$ up to the value resulting from graphical needs, that is, from the scale for ppr1 assumed to plot the related (e.g., speciation) curves. If the solubility product for pr1 is attained at defined point of the dissolution process, then upper value assumed for ppr1 is the value corresponding to this point.

The iterative computer programs are usually designed for the curve-fitting procedures where the degree of fitting of a curve to experimental points is finite. In particular case, the criterion of optimization is based on differences $F(\mathbf{x}(\operatorname{ppr} 1(N+1)))-F(\mathbf{x}(\operatorname{ppr} 1(N)))$ between two successive ( $N$ th and $N+1$ th) approximations of the $F$-value, and the optimisation is terminated if the inequality

$$
|F(\mathbf{x}(\operatorname{ppr} 1(N+1)))-F(\mathbf{x}(\operatorname{ppr} 1(N)))|<\delta
$$

is valid for any preassumed, sufficiently low $\delta$-value, for example, $\delta=10^{-15}$.

However, one may happen that the condition (14) can be fulfilled at local minimum different from the global minimum. It occurs when the starting values $\mathbf{x}^{*}(\mathrm{ppr} 1)$ are too distant from the true value $\mathbf{x}(\operatorname{ppr} 1)$, where the equality $F(\mathbf{x}(\operatorname{ppr} 1))=0$ is fulfilled. In this case, one should repeat the calculations for a new vector $\mathbf{x}^{*}(\operatorname{ppr} 1)$, guessed at a particular pprl value chosen at the start for minimisation.

All vectors $\mathbf{x}=\mathbf{x}$ (ppr1) obtained for different ppr1 values are the basis for plotting the speciation curves for all species $\left(X_{i}\right)$ in the system. The curves are usually plotted in the logarithmic diagrams, on 2D plane, with ppr1 on the abscissa and $\log \left[X_{i}\right]$ on the ordinate. Other variables, for example, $\mathrm{pH}$ on the abscissa, can also be applied.

\section{Simulated Dedolomitisation}

4.1. Preliminary Data. We refer first to aqueous solutions obtained before introducing pr1 into it. Any particular solution is characterised by $\mathrm{pC}_{\mathrm{CO}_{2}}=-\log C_{\mathrm{CO}_{2}}$ and $\mathrm{pH}=$ $\mathrm{pH}_{0}$ values, where $\mathrm{pC}_{\mathrm{CO}_{2}}$ equals $2,3,4,5$, or $\infty$ (the latter value refers to $C_{\mathrm{CO}_{2}}=0$ ) and $\mathrm{pH}_{0}$ values cover the set of natural numbers within the interval $\langle 3,12\rangle$. The $\mathrm{pH}_{0}$ value corresponds to the presence of a strong acid $\left(\mathrm{HB}, \mathrm{C}_{a} \mathrm{~mol} / \mathrm{L}\right)$ or strong base $\left(\mathrm{MOH}, \mathrm{C}_{b} \mathrm{~mol} / \mathrm{L}\right)$, see $(8)$. The solution is then characterised by a defined pair of $\left(\mathrm{pC}_{\mathrm{CO}_{2}}, \mathrm{pH}_{0}\right)$ values.

After introducing pr1 into the solution, its initial $(t=$ $0)$ concentration in the two-phase system equals $[\mathrm{pr} 1]_{t=0}=$ $C_{0} \mathrm{~mol} / \mathrm{L}$. Two values for $\mathrm{p} C_{0}=-\log C_{0}$, equal 2 and 3 , were assumed. The set of parameters $\left(\mathrm{p} C_{0}, \mathrm{pC}_{\mathrm{CO}_{2}}, \mathrm{pH}_{0}\right)$ assumed involves a multitude of different phenomena occurred in the system considered. The examples presented in the follwing concern only some particular cases.

The volume change of the system, affected by addition of pr1, can be neglected. The volume changes, involved with further dissolution and formation of precipitates, are neglected too. In order to neglect the diffusion effects, the systems were (virtually) mixed (homogenised). The dissolution has been considered as a quasistatic process, carried out under isothermal conditions.

4.2. Discussion on Particular Systems. At the first stage of the process that occurred after pr1 addition, the solution is unsaturated against any particular precipitate, that is, $q_{i}<1$ ( $i=$ $1, \ldots, 5)$ in (6). At defined point, it saturates against another precipitate. As will be stated in the following, two different precipitates: pr $2=\mathrm{CaCO}_{3}$ or pr $5=\mathrm{Mg}(\mathrm{OH})_{2}$, are formed in the systems considered. Then the solution saturates against pr1 or transforms wholly to the second precipitate; in the latter case, the saturation towards pr1 is not attained. At a relatively high $C_{\mathrm{CO}_{2}}$ value, pr1 dissolves wholly and no other precipitate is formed $\left(q_{i}<1\right)$. The curves expressing the relations (9) and (10) are referred to unsaturated solutions in nonequilibrium systems and termed dissolution curves. The curves expressing the relations (9) and (10), when referred to the solutions saturated against a particular precipitate, are termed the solubility curves $\left(\sum \mathrm{Me} \leq s_{\mathrm{Me}}, \mathrm{Me}=\mathrm{Ca}, \mathrm{Mg}\right)$. The dissolution curves presented below are then terminated:

(a) by the bifurcation point, where the solubility product $\left(K_{\text {spi }}\right)$ for the corresponding precipitate (pr2 or pr5) is attained $\left(q_{2}=1\right.$ or $\left.q_{5}=1\right)$, or

(b) by the point, where $[\operatorname{pr} 1]=0$ at $q_{i}<1(i=1, \ldots, 5)$, that is, prl dissolves wholly. 


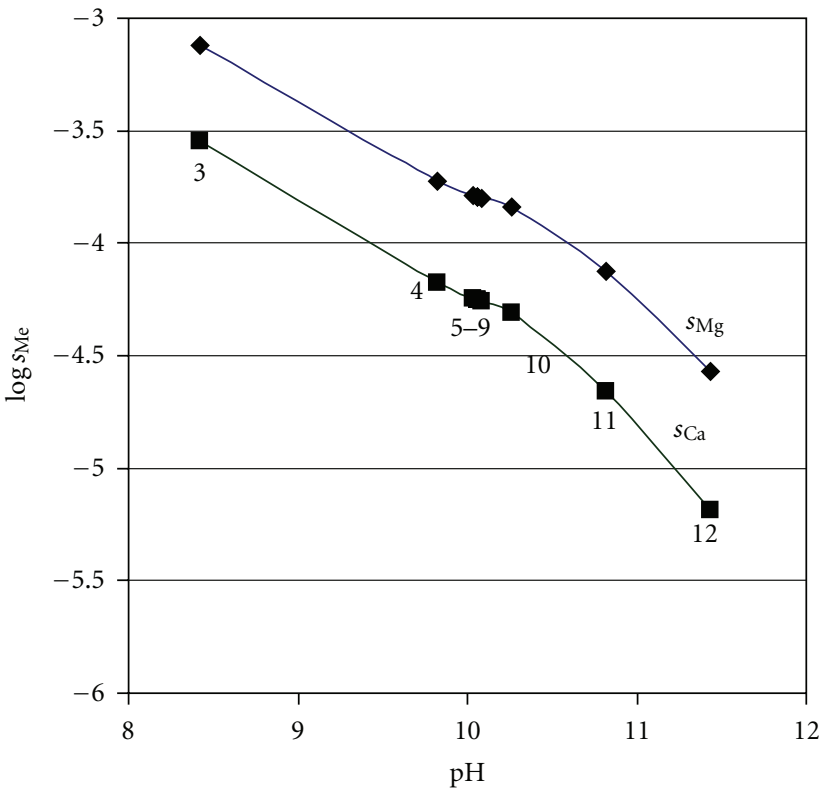

(a)

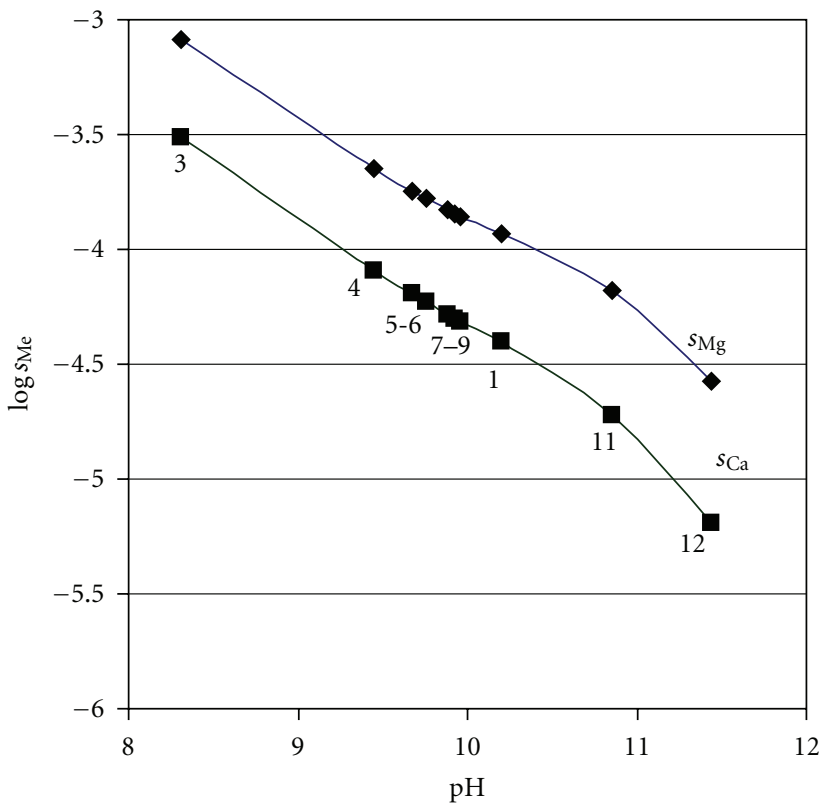

(c)

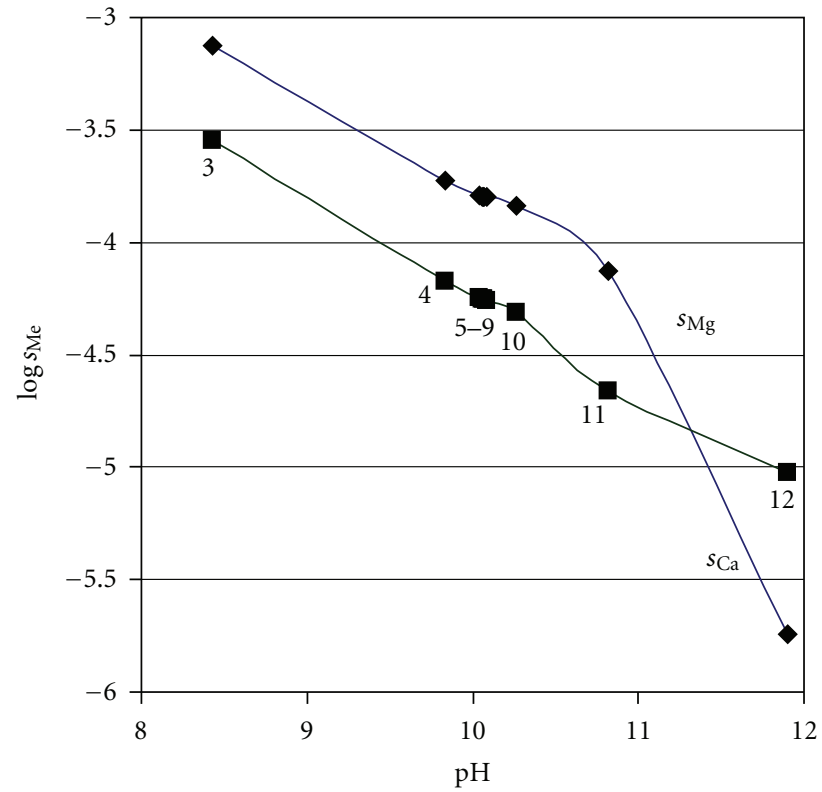

(b)

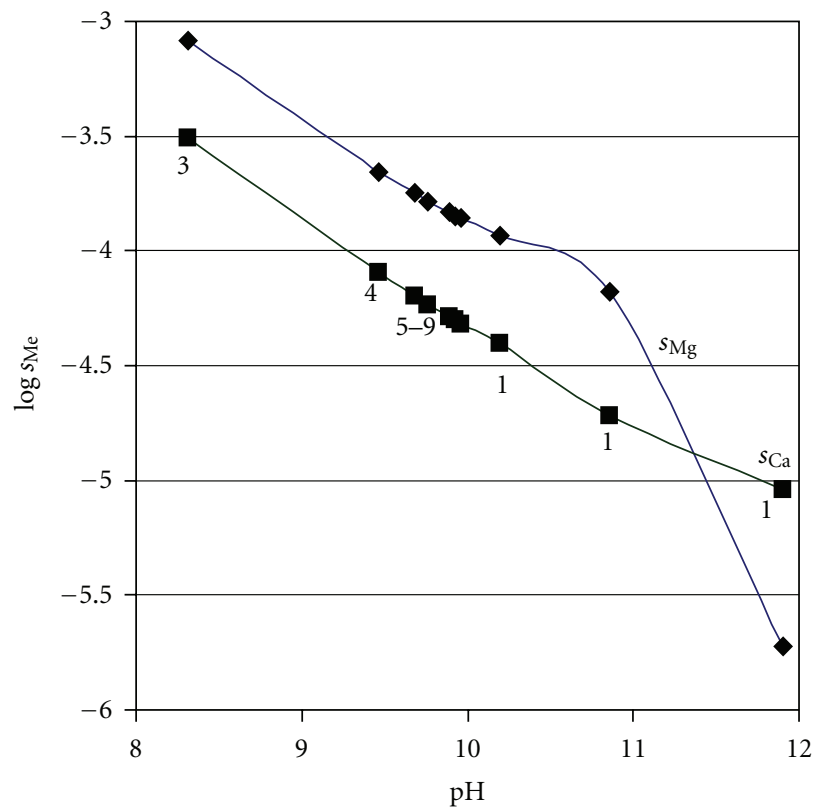

(d)

Figure 3: The $\log s_{\mathrm{Me}}$ versus $\mathrm{pH}$ relationships $(\mathrm{Me}=\mathrm{Ca}, \mathrm{Mg})$ plotted at $\mathrm{p} K_{\mathrm{sp} 1}=16.54$ for $\mathrm{pr} 1, \sum \mathrm{Me}=s_{\mathrm{Me}}((9),(10))$ at different $\left(\mathrm{p} C_{0}\right.$, $\mathrm{pC}_{\mathrm{CO}_{2}}$ ) values: (a) $(2, \infty)$; (b) $(3, \infty)$; (c) $(2,4)$; (d) $(3,4)$; the numbers at the corresponding points correspond to $\mathrm{pH}_{0}$ values.

The dissolution/solubility curves, obtained at $\mathrm{p} C_{0}=2$ and 3, are plotted in Figures 1(a)-1(d), for different $\mathrm{pH}_{0}$ and $\mathrm{pC}_{\mathrm{CO}_{2}}$ values. The curves plotted in Figures $1(\mathrm{c})$ and $1(\mathrm{~d})$ refer to different sets of $\left(\mathrm{pC}_{0}, \mathrm{pC}_{\mathrm{CO}_{2}}, \mathrm{pH}_{0}\right)=\left(3, \mathrm{pC}_{\mathrm{CO}_{2}}, \mathrm{pH}_{0}\right)$ values. When $C_{\mathrm{CO}_{2}}$ exceeds distinctly the $C_{0}$ value $\left(\mathrm{p} C_{0}=3\right)$, pr1 dissolves wholly before the solubility product for $\mathrm{pr} 2$ is attained.

The plots for soluble species consisting the expressions for $\sum \mathrm{Ca}$ and $\sum \mathrm{Mg}((9),(10))$ and referred to different sets of $\left(\mathrm{pC}_{0}, \mathrm{pC}_{\mathrm{CO}_{2}}, \mathrm{pH}_{0}\right)$ values are presented in Figures $2(\mathrm{a})$ and 2(b) (for $\mathrm{p} C_{0}=2$ ) and Figures 2(c) and 2(d) (for $\mathrm{p} C_{0}=3$ ).
As results from the course of speciation curves plotted in Figure 2, the first (dissolution) step can be represented by reactions:

$$
\begin{gathered}
\operatorname{prl}+2 \mathrm{H}_{2} \mathrm{O}=\mathrm{Ca}^{+2}+\mathrm{Mg}^{+2}+2 \mathrm{HCO}_{3}{ }^{-1}+2 \mathrm{OH}^{-1}, \\
\operatorname{pr} 1+\mathrm{H}_{2} \mathrm{O}=\mathrm{Ca}^{+2}+\mathrm{Mg}^{+2}+\mathrm{HCO}_{3}{ }^{-1}+\mathrm{CO}_{3}{ }^{-2}+\mathrm{OH}^{-1}, \\
\operatorname{prl}=\mathrm{Ca}^{+2}+\mathrm{Mg}^{+2}+2 \mathrm{CO}_{3}^{-2},
\end{gathered}
$$




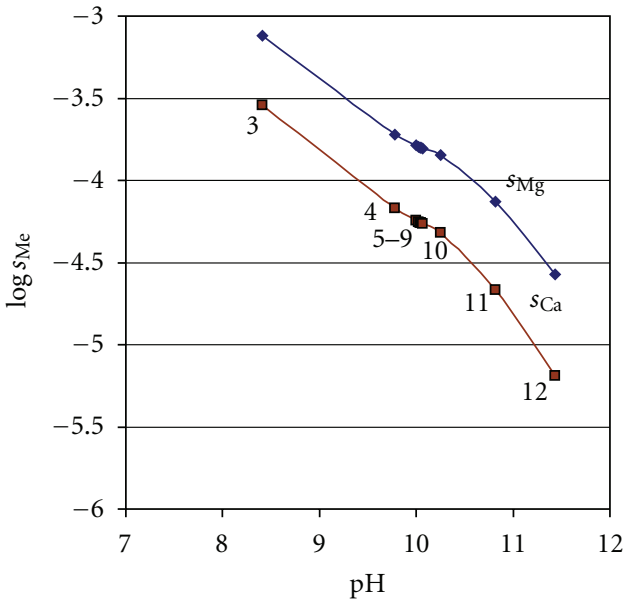

(a)

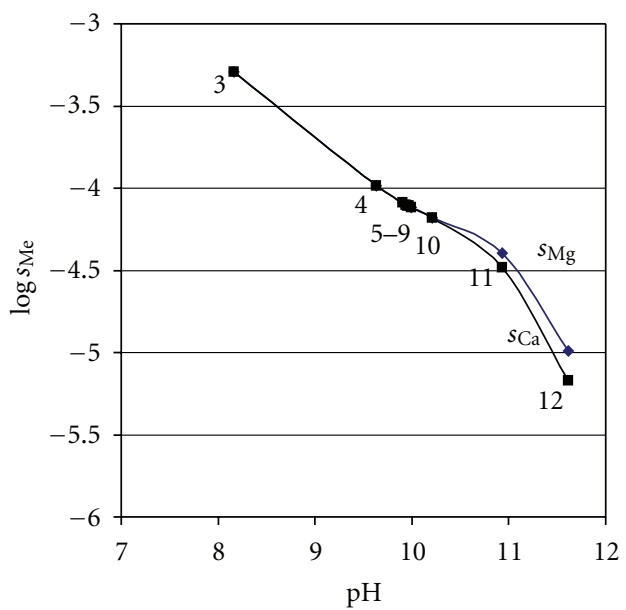

(c)

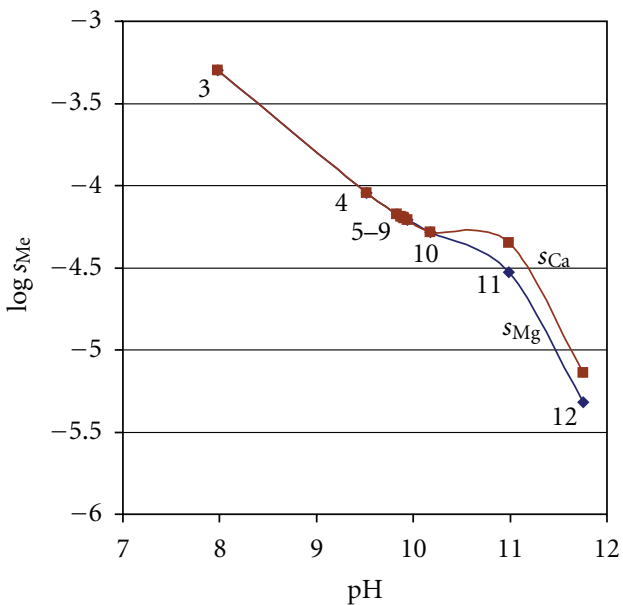

(e)

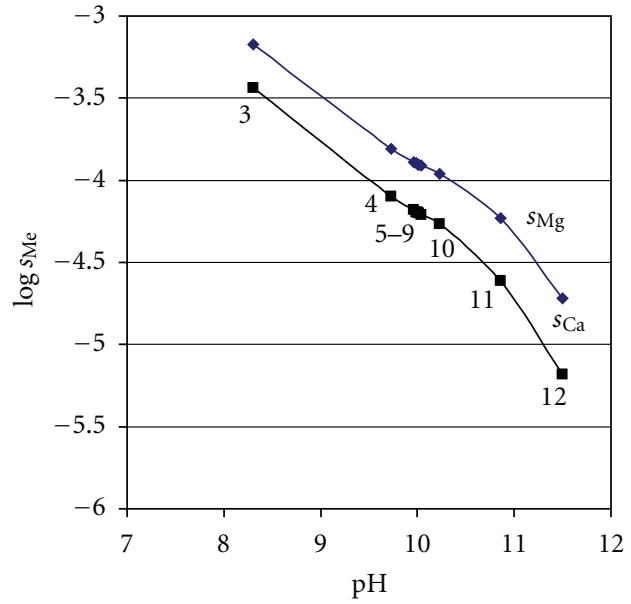

(b)

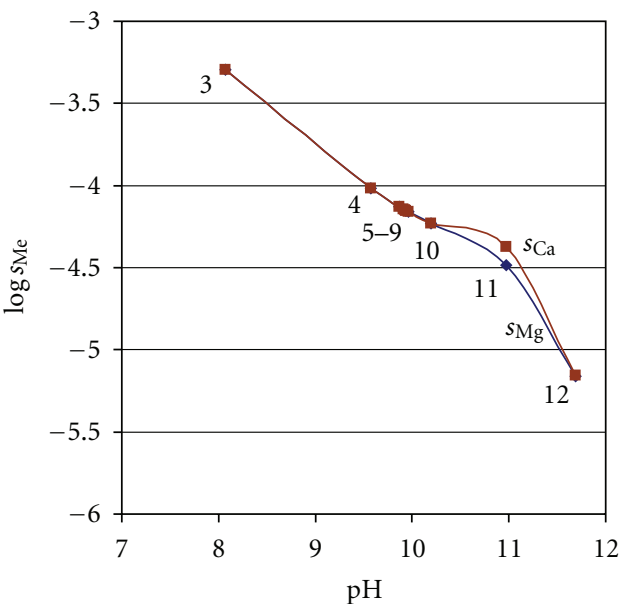

(d)

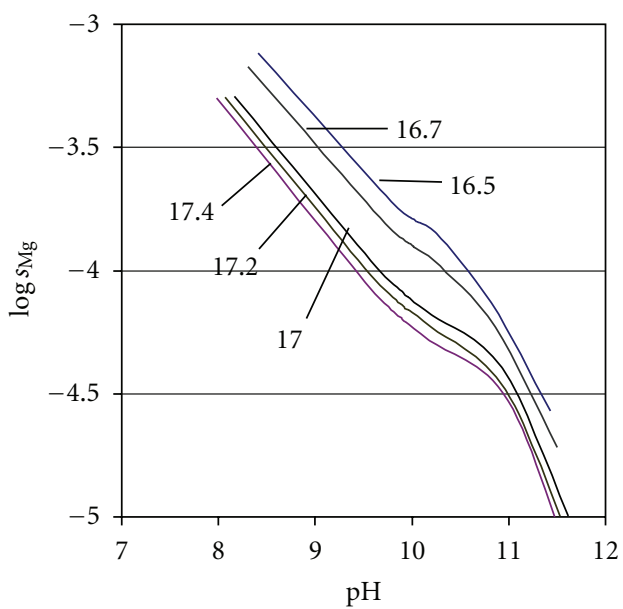

(f)

FIGURE 4: The $\log s_{\mathrm{Me}}$ versus $\mathrm{pH}$ relationships ( $\sum \mathrm{Me}=s_{\mathrm{Me}}$ in $(9),(10)$ at $\left(\mathrm{p} C_{0}, \mathrm{p} C_{\mathrm{CO}_{2}}\right)=(2,5)$ for different $\mathrm{p} K_{\text {spl } 1}$ values assumed for prl: (a) 16.54; (b) 16.7 ; (c) 17.0 ; (d) 17.2 ; (e) 17.4; (f) collected effect of $K_{\text {sp1 }}$ values (indicated at the corresponding curves) on log $s_{\mathrm{Mg}}$ value. 


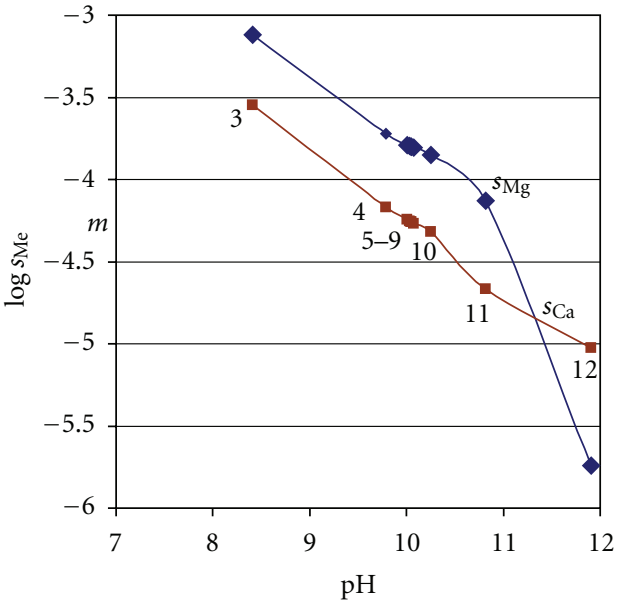

(a)

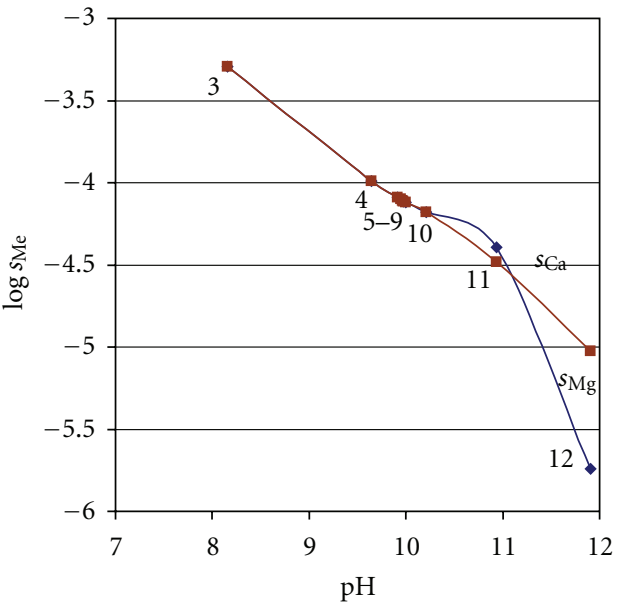

(c)

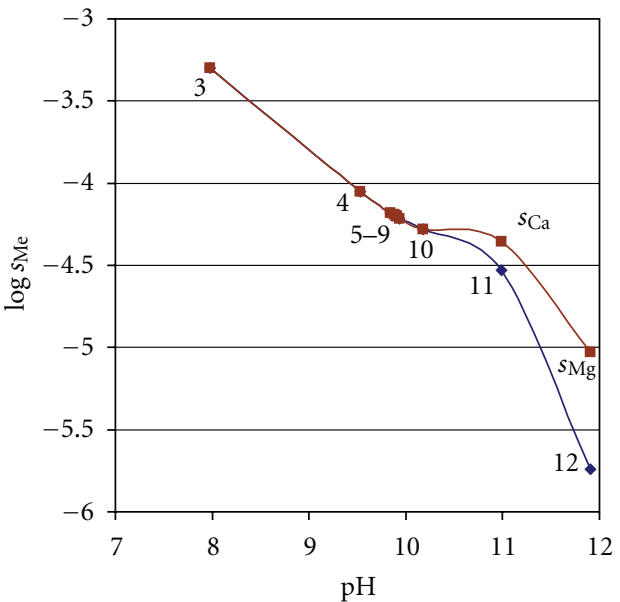

(e)

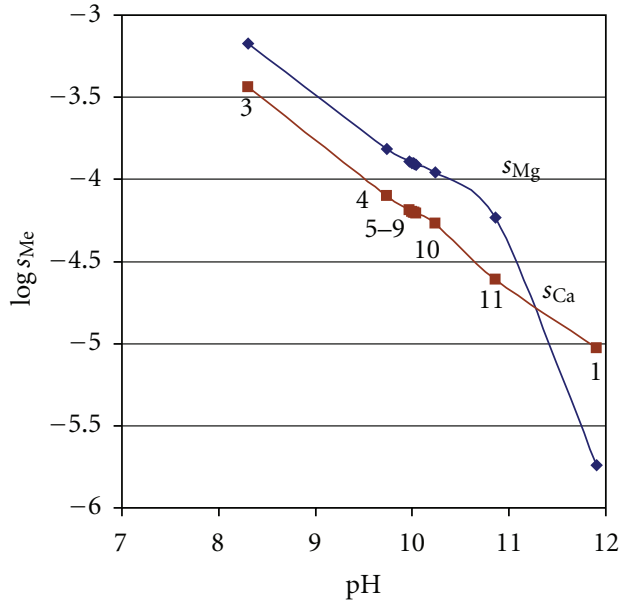

(b)

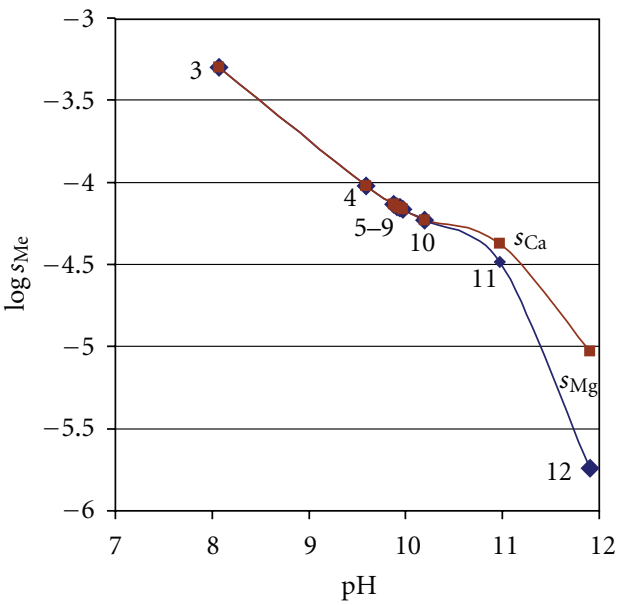

(d)

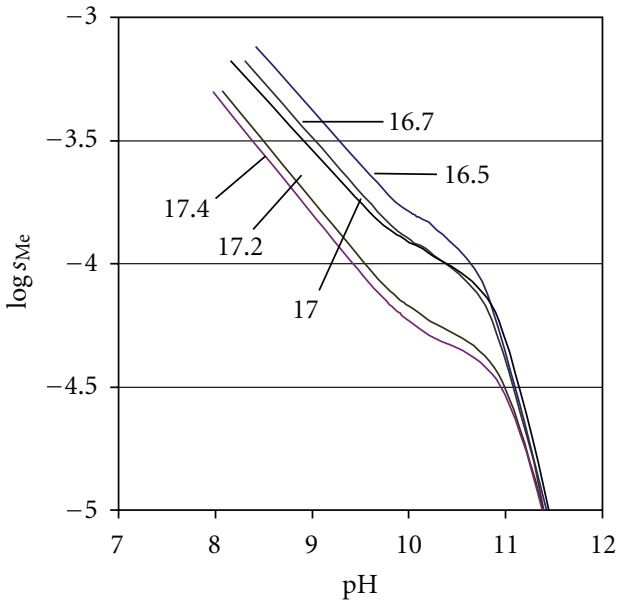

(f)

Figure 5: The $\log s_{\mathrm{Me}}$ versus $\mathrm{pH}$ relationships $\left(\sum \mathrm{Me}=s_{\mathrm{Me}}\right.$ in $\left.(9),(10)\right)$ at $\left(\mathrm{p} C_{0}, \mathrm{pC}_{\mathrm{CO}_{2}}\right)=(3,5)$ for different $\mathrm{p} K_{\mathrm{sp} 1}$ values assumed for pr1: (a) 16.54 ; (b) 16.7 ; (c) 17.0 ; (d) 17.2 ; (e) 17.4 ; (f) collected effect of $\mathrm{p} K_{\mathrm{sp} 1}$ values (indicated at the corresponding curves) on $\log s_{\mathrm{Mg}}$ value. 
where soluble species are formed. At the bifurcation points, the solubility product for pr2 is attained $\left(q_{2}=1\right)$ and then pr2 is precipitated:

$$
\begin{gathered}
\operatorname{pr} 1+\mathrm{Ca}^{+2}=2 \operatorname{pr} 2+\mathrm{Mg}^{+2} \\
\operatorname{pr} 1+\mathrm{H}_{2} \mathrm{O}=\operatorname{pr} 2+\mathrm{Mg}^{+2}+\mathrm{HCO}_{3}^{-1}+\mathrm{OH}^{-1}
\end{gathered}
$$

The soluble magnesium species evolved into the solution, as the result of transformation of pr1 into pr2, are represented by m-lines, referred to (9); each of the m-lines terminates at the point where the solubility product $\left(K_{\mathrm{sp} 1}\right)$ for prl is attained (i.e., $q_{1}=1$ ) and further dissolution of prl is stopped. As we see, the $\mathrm{pH}$ values corresponding to the bifurcation points are lowered with growth of $C_{\mathrm{CO}_{2}}$ value. The growth in $\mathrm{C}_{\mathrm{CO}_{2}}$ causes also a significant growth in dissolution/solubility values.

The points where the solubility product $\left(\mathrm{p} K_{\mathrm{sp} 1}=16.54\right)$ for $\mathrm{pr} 1$ is attained $\left(q_{1}=1\right)$ at the same pair of $\left(\mathrm{p} C_{0}, \mathrm{pC}_{\mathrm{CO}_{2}}\right)$ values and different $\mathrm{pH}_{0}$ values are marked and connected by lines on the corresponding plots in Figure 3. In the middle part of the resulting curves, the points are grouped together, within a small area.

The course of the related plots is affected by $\mathrm{p} K_{\mathrm{sp} 1}$ value, assumed for solubility product of dolomite (pr1), as indicated in Figure 4 (for $\mathrm{p} C_{0}=2$ ) and Figure 5 (for $\mathrm{p} C_{0}=3$ ). The points referred to different $\mathrm{pH}_{0}$ values were omitted there, for brevity.

4.3. Solubility Curves for Dolomite Plotted at Different Preassumed $p K_{s p 1}$ Values. As has been stated above, the values for $\mathrm{p} K_{\mathrm{spd}}$ attainable in the literature differ in wide range of values: from 16.54 to 19.35 . Except the troubles involved with dolomite stoichiometry, these (serious) discrepancies in $\mathrm{p} K_{\mathrm{sp} 1}$ value are affected by (and resulted from) differences in solubility of calcite and magnesite. Namely, calcite constituent of dolomite dissolved more rapidly than magnesite constituent [27]. These effects, together with possible nonstoichiometry of dolomite (i.e., formation of magnesian calcite), make the system with dolomite a highly complicated one.

The speciation curves for dolomite are plotted at $\mathrm{pC}_{\mathrm{CO}_{2}}=5$ and $\mathrm{p} C_{0}=2$ and different $\mathrm{p} K_{\mathrm{sp} 1}$ values; it results that at $\mathrm{p} K_{\mathrm{sp} 1}$ equal 16.54 and 16.7 , the equilibrium solid phase is calcite. However, when $\mathrm{pH}$ of the solution is greater than the boundary (minimal) value, the solid phase contains two equilibrium precipitates: calcite and dolomite. However, for $\mathrm{p} K_{\mathrm{spl}}=17$ at lower $\mathrm{pH}$ values, the equilibrium solid phase is dolomite and calcite appears as the second equilibrium solid phase at $\mathrm{pH}$ greater than ca. 10.2. At $\mathrm{p} K_{\mathrm{sp} 1}=$ 19.35 , calcite is not formed. The curves of $\log \left[X_{i}\right]$ versus $\mathrm{pH}$ relationships plotted for different species $X_{i}$ (i.e., precipitates: pr1, pr2 and soluble complexes: $\mathrm{Mg}^{+2}, \mathrm{Ca}^{+2}$, $\left.\mathrm{MgHCO}_{3}{ }^{+1}, \mathrm{CaHCO}_{3}{ }^{+1}, \mathrm{MgCO}_{3}, \mathrm{CaCO}_{3}\right)$ are terminated at $\mathrm{pH}$ where the solubility product $\left(K_{\mathrm{sp} 5}\right)$ for pr5 is attained. The plots of solubility curves for magnesium and calcium differ significantly at $\mathrm{p} K_{\mathrm{sp} 1}$ equal 16.54 and 16.7. At $\mathrm{p} K_{\mathrm{sp} 1}=$ 17 , the plots bifurcate at higher $\mathrm{pH}$ values. At $\mathrm{p} K_{\mathrm{spl}}=19.35$, both plots overlap.
Some thermodynamic data given above are modified, to some degree, by kinetic effects. Namely, from the data referred to dissolution of dolomite into solutions with different $\mathrm{pH}_{0}$ [27] or $\mathrm{pH}_{0}$ and $\mathrm{p}\left(\mathrm{CO}_{2}\right)$ [29] values, it results that overall effectiveness of dolomite dissolution is largely affected (limited) by dissolution of pr3 component, owing to the fact that pr2 in dolomite dissolves faster than pr3.

\section{Final Comments}

The paper provides the calculation procedure that enables some changes in speciation in the system with dissolving dolomite to be followed. In each case, the dissolution was considered as a quasistatic, isothermal process. The dissolution concept refers to the systems where solubility product of the related precipitate has not been crossed yet. The dissolution has been considered under different conditions, expressed by (a) concentration of the solid phase $\left(C_{0} \mathrm{~mol} / \mathrm{L}\right)$, (b) concentration $\left(\mathrm{C}_{\mathrm{CO}_{2}} \mathrm{~mol} / \mathrm{L}\right)$ of $\mathrm{CO}_{2}$, and (c) concentration of a strong acid $\left(C_{a} \mathrm{~mol} / \mathrm{L}\right)$ or base $\left(C_{b} \mathrm{~mol} / \mathrm{L}\right)$, expressed by the value $\Delta=C_{b}-C_{a}$. The procedure applied enables the concentrations of particular species formed at different $\mathrm{pH}$ of the solution to be calculated at different moments of the dolomite dissolution. This way, the dissolution $\left(\sum \mathrm{Me}, \mathrm{mol} / \mathrm{L}\right)$ value was plotted. At the end of the dissolution process, $\sum \mathrm{Me}$ assumes its limiting value, equal to the solubility $\left(s_{\mathrm{Me}}, \mathrm{mol} / \mathrm{L}\right)$, that is, $\sum \mathrm{Me}=s_{\mathrm{Me}}$. As results from the examples quoted, in some instances the solubility product of other (different from the dissolving) solid phases is crossed. Higher (relative) concentration of $\mathrm{CO}_{2}$ in the solution promotes the dissolution of dolomite.

\section{Symbols}

$C_{0}$ : initial concentration $(\mathrm{mol} / \mathrm{L})$ of dolomite $(\mathrm{pr} 1)$ in two-phase system

$C_{b}, C_{a}$ : concentrations $(\mathrm{mol} / \mathrm{L})$ of $\mathrm{KOH}$ or $\mathrm{HCl}$, respectively, in the initial solution $\Delta=C_{b}-C_{a}$

$K_{\text {sp1-5: }}$ solubility products for $\mathrm{CaMg}\left(\mathrm{CO}_{3}\right)_{2}(\mathrm{pr} 1)$, $\mathrm{CaCO}_{3}$ (pr2), $\mathrm{MgCO}_{3}(\mathrm{pr} 3), \mathrm{Ca}(\mathrm{OH})_{2}(\mathrm{pr} 4)$; $\mathrm{Mg}(\mathrm{OH})_{2}$ (pr5), respectively

$M_{i}$ : molar mass $(\mathrm{g} / \mathrm{mol})$ of pri

$\mathrm{p} C_{0}=-\log C_{0}$ $\mathrm{pC}_{\mathrm{CO}_{2}}=-\log C_{\mathrm{CO}_{2}}$ $\mathrm{p} K_{\text {spi }}=-\log K_{\text {spi }}(i=1, \ldots, 5)$

[pri]: molar conc. of pri

$s: \quad$ Solubility $(\mathrm{mol} / \mathrm{L})$

$t$ : time.

\section{References}

[1] J. Warren, "Dolomite: occurence, evolution and economically important associations," Earth Science Reviews, vol. 52, no. 13, pp. 1-81, 2000.

[2] M. Schmidt, S. Xeflide, R. Botz, and S. Mann, "Oxygen isotope fractionation during synthesis of $\mathrm{CaMg}$-carbonate and implications for sedimentary dolomite formation," Geochimica et Cosmochimica Acta, vol. 69, no. 19, pp. 4665-4674, 2005. 
[3] R. S. Arvidson and F. T. Mackenzie, "Tentative kinetic model for dolomite precipitation rate and its application to dolomite distribution," Aquatic Geochemistry, vol. 2, no. 3, pp. 273-298, 1996.

[4] T. Michalowski, M. Borzęcka, M. Toporek, S. Wybraniec, P. Maciukiewicz, and A. Pietrzyk, "Quasistatic processes in nonequilibrium two-phase systems with ternary salts: II. Dolomite + Aqueous media," Chemia Analityczna, vol. 54, no. 6, pp. 1203-1217, 2009.

[5] http://www.webelements.com/.

[6] L. Chai, A. Navrotsky, and R. J. Reeder, "Energetics of calciumrich dolomite," Geochimica et Cosmochimica Acta, vol. 59, no. 5, pp. 939-944, 1995.

[7] E. Busenberg and L. Niel Plummer, "Thermodynamics of magnesian calcite solid-solutions at $25^{\circ} \mathrm{C}$ and 1 atm total pressure," Geochimica et Cosmochimica Acta, vol. 53, no. 6, pp. 1189-1208, 1989.

[8] W. D. Bischoff, F. T. Mackenzie, and F. C. Bishop, "Stabilities of synthetic magnesian calcites in aqueous solution: comparison with biogenic materials," Geochimica et Cosmochimica Acta, vol. 51, no. 6, pp. 1413-1423, 1987.

[9] M. A. Bertram, F. T. Mackenzie, F. C. Bishop, and W. D. Bischoff, "Influence of temperature on the stability of magnesian calcite," American Mineralogist, vol. 76, no. 11-12, pp. 1889-1896, 1991.

[10] J. S. Tribble, R. S. Arvidson, M. Lane, and F. T. Mackenzie, "Crystal chemistry, and thermodynamic and kinetic properties of calcite, dolomite, apatite, and biogenic silica: applications to petrologic problems," Sedimentary Geology, vol. 95, no. 1-2, pp. 11-37, 1995.

[11] M. J. Malone, P. A. Baker, and S. J. Burns, "Recrystallization of dolomite: an experimental study from $50-200^{\circ} \mathrm{C}$," Geochimica et Cosmochimica Acta, vol. 60, no. 12, pp. 2189-2207, 1996.

[12] B. D. Evamy, "Dedolomitization and the development of rhombohedral pores in limestones," Journal of Sedimentary Petrology, vol. 37, no. 4, pp. 1204-1215, 1967.

[13] C. Ayora, C. Taberner, M. W. Saaltink, and J. Carrera, “The genesis of dedolomites: a discusion based on reactive transport modeling," Journal of Hydrology, vol. 209, no. 1-4, pp. 346365, 1998.

[14] D. Bernoulli and B. Gunzenhauser, "A dolomitized diatomite in an Oligocene-Miocene deep-sea fan succession, Gonfolite Lombarda group, Northern Italy," Sedimentary Geology, vol. 139, no. 1, pp. 71-91, 2001.

[15] E. García, P. Alfonso, E. Tauler, and S. Galí, "Surface alteration of dolomite in dedolomitization reaction in alkaline media," Cement and Concrete Research, vol. 33, no. 9, pp. 1449-1456, 2003.

[16] D. A. Budd, "Cenozoic dolomites of carbonate islands: their attributes and origin," Earth-Science Reviews, vol. 42, no. 1-2, pp. 1-47, 1997.

[17] C. Reinhold, "Multiple episodes of dolomitization and dolomite recrystallization during shallow burial in Upper Jurassic shelf carbonates: Eastern Swabian Alb, southern Germany," Sedimentary Geology, vol. 121, no. 1-2, pp. 71-95, 1998.

[18] P. V. Brady, J. L. Krumhansl, and H. W. Papenguth, "Surface complexation clues to dolomite growth," Geochimica et Cosmochimica Acta, vol. 60, no. 4, pp. 727-731, 1996.

[19] I. Stratful, M. D. Scrimshaw, and J. N. Lester, "Conditions influencing the precipitation of magnesium ammonium phosphate," Water Research, vol. 35, no. 17, pp. 4191-4199, 2001.

[20] M. Gautelier, E. H. Oelkers, and J. Schott, "An experimental study of dolomite dissolution rates as a function of $\mathrm{pH}$ from -0.5 to 5 and temperature from 25 to $80^{\circ} \mathrm{C}$," Chemical Geo$\log y$, vol. 157, no. 1-2, pp. 13-26, 1999.
[21] J. E. Gillott, "Alkali-reactivity problems with emphasis on canadian aggregates," Engineering Geology, vol. 23, no. 1, pp. 29-43, 1986.

[22] T. Michałowski and A. Pietrzyk, "A thermodynamic study of struvite + water system," Talanta, vol. 68, no. 3, pp. 594-601, 2006.

[23] T. Michałowski and A. Pietrzyk, "Quasistatic processes in nonequilibrium two-phase systems with ternary salts: I. Struvite + Aqueous solution (CO2 + KOH)," Chemia Analityczna, vol. 53 , no. 1, pp. 33-46, 2008.

[24] K. Lund, H. S. Fogler, C. C. McCune, and J. W. Ault, "Acidization-II. The dissolution of calcite in hydrochloric acid," Chemical Engineering Science, vol. 30, no. 8, pp. 825-835, 1975.

[25] H. W. Rauch and W. B. White, "Dissolution kinetics of carbonate rocks - 1. Effects of lithology on dissolution rate," Water Resources Research, vol. 13, no. 2, pp. 381-394, 1977.

[26] H. A. Wanas, "Petrography, geochemistry and primary origin of spheroidal dolomite from the Upper Cretaceous/Lower Tertiary Maghra El-Bahari Formation at Gabal Ataqa, Northwest gulf of Suez, Egypt," Sedimentary Geology, vol. 151, no. 3-4, pp. 211-224, 2002.

[27] L. Chou, R. M. Garrels, and R. Wollast, "Comparative study of the kinetics and mechanisms of dissolution of carbonate minerals," Chemical Geology, vol. 78, no. 3-4, pp. 269-282, 1989.

[28] J. S. Herman and W. B. White, "Dissolution kinetics of dolomite: effects of lithology and fluid flow velocity," Geochimica et Cosmochimica Acta, vol. 49, no. 10, pp. 2017-2026, 1985.

[29] E. Busenberg and L. N. Plummer, "The kinetics of dissolution of dolomite in $\mathrm{CO}_{2}-\mathrm{H}_{2} \mathrm{O}$ systems at 1.5 to $65^{\circ} \mathrm{C}$ and 0 to $1 \mathrm{~atm}$ $\mathrm{PCO}_{2}$," American Journal of Science, vol. 282, no. 1, pp. 45-78, 1982.

[30] J. V. Macpherson and P. R. Unwin, "Recent advances in kinetic probes of the dissolution of ionic crystals," Progress in Reaction Kinetics, vol. 20, no. 3, pp. 185-244, 1995.

[31] Z. Zhang and G. H. Nancollas, "Mechanisms of growth and dissolution of sparingly soluble salts," Reviews in Mineralogy and Geochemistry, vol. 23, no. 1, pp. 365-396, 1990.

[32] M. B. Tomson and G. H. Nancollas, "Mineralization kinetics: a constant composition approach," Science, vol. 200, no. 4345, pp. 1059-1060, 1978.

[33] D. R. Boomer, C. C. McCune, and H. S. Fogler, "Rotating disk apparatus for reaction rate studies in corrosive liquid environments," Review of Scientific Instruments, vol. 43, no. 2, pp. 225229, 1972.

[34] A. F. M. Barton and S. R. McConnel, "Dissolution behaviour of solids: the rotating disc method," Chemistry in Australia, vol. 46, pp. 427-433, 1979.

[35] D. Hofmann and F. Moll, "The effect of ultrasonics on the dissolution rate of powdered drugs," European Journal of Pharmaceutics and Biopharmaceutics, vol. 40, no. 3, pp. 142146, 1994.

[36] E. Usdovski, "Synthesis of dolomite and geochemical implications," in Dolomites: A Volume in Honour of Dolomieu, B. Purser et al., Ed., pp. 345-360, Blackwell Sci. Publ, Oxford, UK, 1994.

[37] L. A. Sherman and P. Barak, "Solubility and dissolution kinetics of dolomite in Ca-Mg- $\mathrm{HCO}_{3} / \mathrm{CO}_{3}$ solutions at $25^{\circ} \mathrm{C}$ and 0.1 MPa carbon dioxide," Soil Science Society of America Journal, vol. 64, no. 6, pp. 1959-1968, 2000.

[38] D. F. Sibley, S. H. Nordeng, and M. L. Borkowski, "Dolomitization kinetics in hydrothermal bombs and natural settings," Journal of Sedimentary Research A, vol. 64, no. 3, pp. 630-637, 1994. 
[39] J. A. D. Dickson, "Transformation of echinoid Mg calcite skeletons by heating," Geochimica et Cosmochimica Acta, vol. 65, no. 3, pp. 443-454, 2001.

[40] M. El Tabakh, C. Utha-Aroon, J. K. Warren, and B. C. Schreiber, "Origin of dolomites in the Cretaceous Maha Sarakham evaporites of the Khorat Plateau, northeast Thailand," Sedimentary Geology, vol. 157, no. 3-4, pp. 235-252, 2003.

[41] C. M. Yoo and Y. I. Lee, "Origin and modification of early dolomites in cyclic shallow platform carbonates, Yeongheung Formation (Middle Ordovician), Korea," Sedimentary Geology, vol. 118, no. 1-4, pp. 141-157, 1998.

[42] C. Rodríguez-Navarro, E. Sebastián, and M. RodríguezGallego, "An urban model for dolomite precipitation: authigenic dolomite on weathered building stones," Sedimentary Geology, vol. 109, no. 1-2, pp. 1-11, 1997.

[43] M. Schmidt, S. Xeflide, R. Botz, and S. Mann, "Oxygen isotope fractionation during synthesis of CaMg-carbonate and implications for sedimentary dolomite formation," Geochimica et Cosmochimica Acta, vol. 69, no. 19, pp. 4665-4674, 2005.

[44] M. El Tabakh, C. Utha-Aroon, J. K. Warren, and B. C. Schreiber, "Origin of dolomites in the Cretaceous Maha Sarakham evaporites of the Khorat Plateau, northeast Thailand," Sedimentary Geology, vol. 157, no. 3-4, pp. 235-252, 2003.

[45] P. M. May and K. Murray, "JESS, a joint expert speciation system-I. Raison d'être," Talanta, vol. 38, no. 12, pp. 1409-1417, 1991.

[46] A. Murray, M. Halliday, and R. J. Croft, "Popliteal artery entrapment syndrome," British Journal of Surgery, vol. 78, no. 12, pp. 1414-1419, 1991.

[47] P. M. May and K. Murray, "JESS, a joint expert speciation system-III. Surrogate functions," Talanta, vol. 40, no. 6, pp. 819-825, 1993.

[48] P. M. May and K. Murray, "Database of chemical reactions designed to achieve thermodynamic consistency automatically," Journal of Chemical and Engineering Data, vol. 46, no. 5, pp. 1035-1040, 2001.

[49] P. W. Jones, D. M. Taylor, and D. R. Williams, "Analysis and chemical speciation of copper and zinc in wound fluid," Journal of Inorganic Biochemistry, vol. 81, no. 1-2, pp. 1-10, 2000.

[50] T. Michałowski, "The generalized approach to electrolytic systems: I. Physicochemical and analytical implications," Critical Reviews in Analytical Chemistry, vol. 40, no. 1, pp. 2-16, 2010.

[51] T. Michałowski, A. Pietrzyk, M. Ponikvar-Svet, and M. Rymanowski, "The generalized approach to electrolytic systems: II. The generalized equivalent mass (GEM) concept," Critical Reviews in Analytical Chemistry, vol. 40, no. 1, pp. 1729, 2010.

[52] A. G. Asuero and T. Michalowski, "Comprehensive formulation of titration curves for complex acid-base systems and its analytical implications," Critical Reviews in Analytical Chemistry, vol. 41, no. 2, pp. 151-187, 2011.

[53] T. Michałowski, "Calculations in Analytical Chemistry with Elements of Computer Programming, PK, Kraków," 2001, http://www.biblos.pk.edu.pl/bcr\&id=1762\&ps=-12\&dir=MD .MichalowskiT.ObliczeniaChemii.html.

[54] T. Michałowski, "Application of GATES and MATLAB for Resolution of Equilibrium, Metastable and Non-Equilibrium Electrolytic Systems," in Applications of MATLAB in Science and Engineering, T. Michałowski, Ed., chapter 1, InTech, 2011.

[55] G. Chen and D. Tao, "Effect of solution chemistry on flotability of magnesite and dolomite," International Journal of Mineral Processing, vol. 74, no. 1-4, pp. 343-357, 2004.
[56] W. Stumm and J. J. Morgan, Aquatic Chemistry. An Introduction Emphasising Chemical Equilibria in Natural Waters, John Wiley and Sons, New York, NY, USA, 1981.

[57] P. M. May and K. Murray, 2001, http://jess.murdoch.edu.au/ jess/jess_home.htm.

[58] J. Y. Gal, J. C. Bollinger, H. Tolosa, and N. Gache, "Calcium carbonate solubility: a reappraisal of scale formation and inhibition," Talanta, vol. 43, no. 9, pp. 1497-1509, 1996.

[59] K. M. Udert, T. A. Larsen, and W. Gujer, "Estimating the precipitation potential in urine-collecting systems," Water Research, vol. 37, no. 11, pp. 2667-2677, 2003.

[60] L. A. Hardie, "Dolomitization; a critical view of some current views," Journal of Sedimentary Petrology, vol. 57, no. 1, pp. $166-183,1987$.

[61] D. K. Nordstrom, L. N. Plummer, D. Langmuir, E. May, H. M. Jones, and D. L. Parkhurst, "Revised chemical equi-librium data for major water mineral reactions and their limitations," in Chemical Modelling of Aqueous Systems, D. C. Melchior and R. L. Basset, Eds., ACS Ser. 416, chapter 31, American Chemical Society, Washington, DC, USA, 1990. 

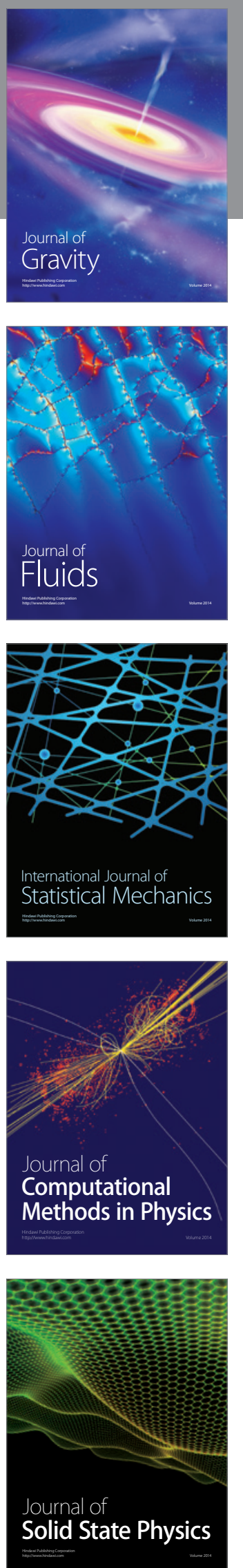

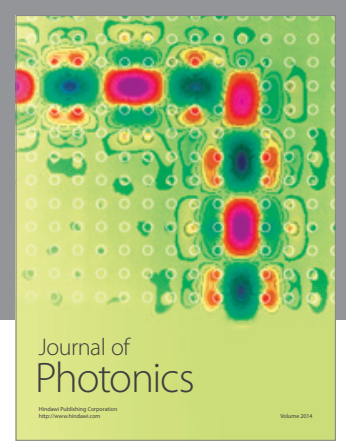

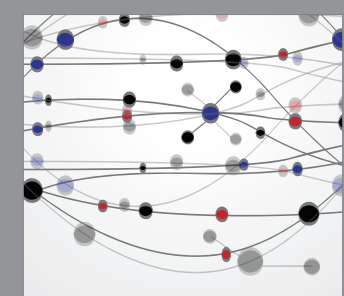

The Scientific World Journal
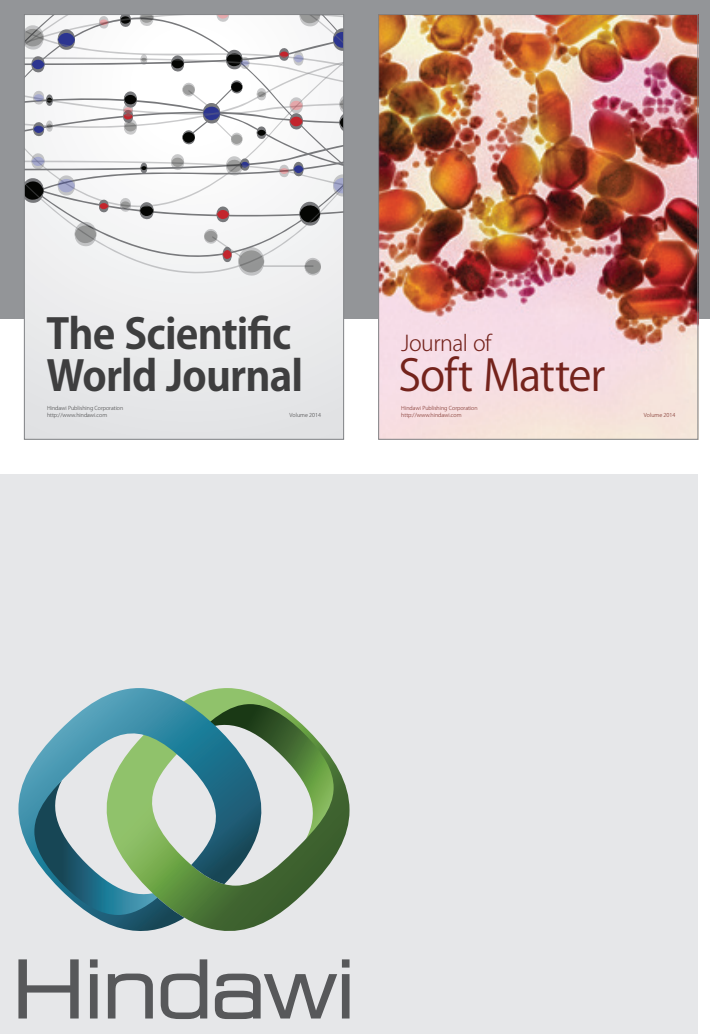

Submit your manuscripts at

http://www.hindawi.com
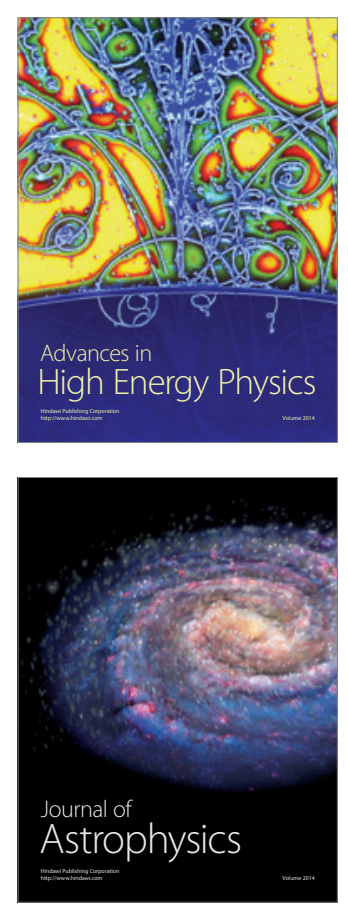
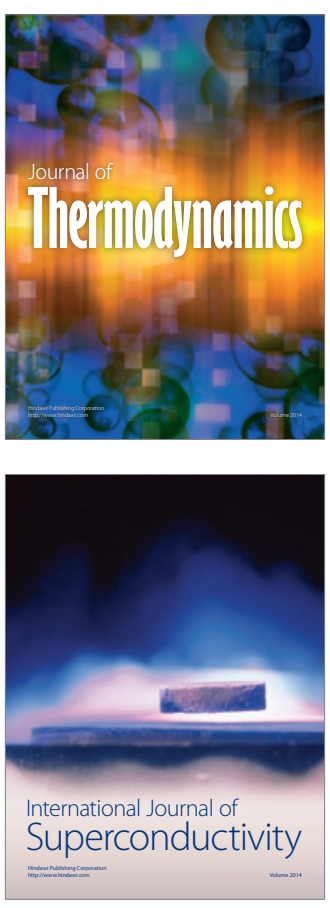
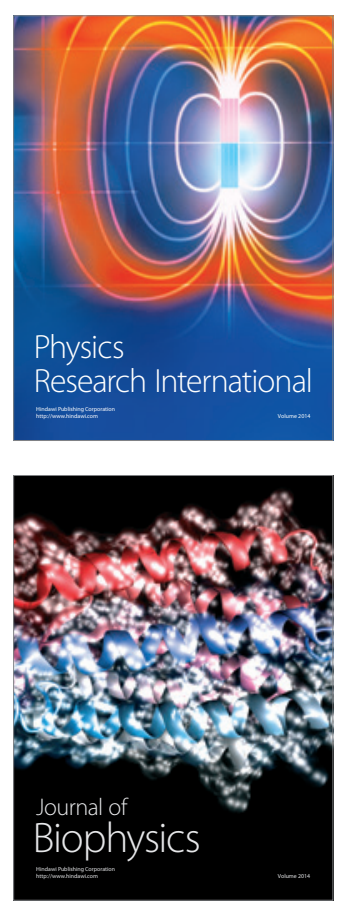
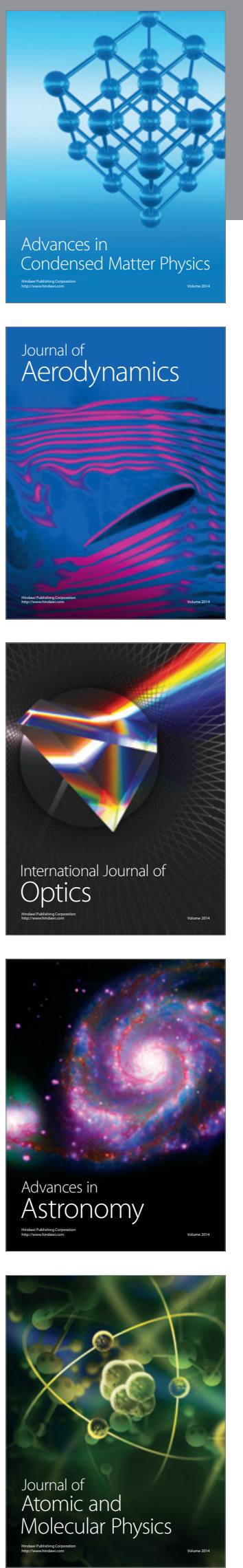